\title{
Military museums in Poland - between the past and the future
}

\author{
Dagmara Chylińska - Łukasz Musiaka
}

\author{
Dagmara Chylińska, PhD \\ University of Wrocław \\ Institute of Geography and Regional Development \\ e-mail: dagmara.chylinska@uwr.edu.pl \\ ORCID: 0000-0003-2517-2856 \\ Lukasz Musiaka, PhD \\ University of Lódź \\ Faculty of Geographical Sciences \\ Department of Political and Historical Geography and Regional Studies \\ e-mail: lukasz.musiaka@geo.uni.lodz.pl
}

ORCID: 0000-0002-6845-7280

\section{Mureológia a kultúrne dedičstvo, 2020, 8:3:5-39 \\ DOI: $10.46284 / \mathrm{mkd} .2020 .8 .3 .1$}

\section{Military museums in Poland - between the past and the future}

Museums are a constantly developing segment of cultural tourism. Poland is in line with current trends in museums, expanding its offer and adapting it to the requirements of the world of contemporary image culture and multisensory experiences, which is increasingly dominated by technology. The authors of the paper undertook to recognise the specificity of military museums, by conducting a survey of approximately a third of all such institutions in Poland. Due to the subject-matter of their exhibitions, military museums create a broad field of research both in terms of aesthetics and museum practice, as well as the issues of shaping and maintaining collective memory and the identity of the nation. They form a special mirror in which the country's ideas and aspirations are reflected more often than any real characteristics. In reference to contemporary trends in museums, the article aims to place Polish military museums between locality and universality, education and entertainment, stability and dynamism, knowledge and experience. The results obtained allowed the authors to distinguish three groups of military museums in Poland, as well as indicate conditions conducive to the further development of such attractions in the country.

Keywords: museum, military museum, heritage, Poland, Central and Eastern Europe.

\section{Introduction}

Since the nineteenth century, when museums became a widely accepted means of collecting, preserving and popularising relics of the past, they have become one of the most popular ways to make cultural heritage accessible to visitors. The concept of the "museum" has undergone far-reaching changes since its inception. ${ }^{1}$ Nowadays, some of the largest museum facilities may aspire to become not only cultural centres but also tourist enterprises. ${ }^{2}$ Among the extremely

${ }^{1}$ GÜNAY, Burcu. Museum concept from past to present and importance of museums as centers of art education. In: Procedia - Social and Behavioral Sciences, 55, 2012, p. 1250-1258; MARSTINE, Janet. Introduction. In: MARSTINE, Janet (ed.). New Museum Theory and Practice. An Introduction. Oxford: Blackwell Publishing, 2006, p. 1-36; ROSS, Max. Interpreting the new museology. In: Museum \& Society, vol. 2, Issue 2, July 2004, p. 84-103; WITCOMB, Andrea. Re-Imagining the Museum. Beyond the Mausoleum. London, New York: Routledge, 2003.

${ }^{2}$ HERREMAN, Yani. Museums and Tourism: Culture and Consumption. In: Museum International, 50:3, July-September 1998, p. 2-64. 
rich museum offer of what we would like to call heritage, collections related to history and military art occupy a prominent place. ${ }^{3}$ This is not a coincidence - world history is largely the history of wars. Military-themed museums often reflect what has shaped nations and what they have been most proud of. The time when the first museums, including military ones, were opened to the general public is also significant. The nineteenth and twentieth centuries were marked by the struggle for the independence of many nations and emerging nationalisms. $\mathrm{Mu}-$ seums helped to build a sense of community based on history and heritage that was understood as the best products of the material and spiritual culture of past generations. The changes in the character of military museums in Poland are treated as part of a paradigm shift in cultural heritage ${ }^{4}$ which took place in the post-war period and represented a departure from the passive protection of monuments to their conservation and, finally, the treatment of heritage as a factor of social and economic development. ${ }^{5}$ Currently, this is resulting in the search for new forms of adaptation and management of change in museums. The contemporary creation of heritage therefore not only involves its protection, but also its creative use. ${ }^{6}$

In the paper, we discuss issues concerning military museums focusing on those located in Poland. In the era of far-reaching political transformations, globalisation and unification processes, and diverse views on the concept of the nation and its function in the present world, we ask questions about the role of military museums in the social and tourism spaces. By establishing the number of military museums in Poland in the twenty-first century and characterising them in terms of values most sought after in contemporary tourism (including authenticity, uniqueness and unconventional interpretation) and in relation to contemporary trends in museums, we aim to place Polish military museums between locality and universality, education and entertainment, stability and dynamism, knowledge and experience. In order to achieve these goals, it was necessary to formulate two research questions:

- to what extent do these museums follow the profound conceptual changes of the contemporary "museum";

- $\quad$ can we make some categorisation of Polish military museums and is there a clear specificity of this type of museum? If so, what is it?

The paper is structured as follows. The first section discusses the development of the concept of the museum in history in order to present explicitly the "old" and the "modern" model of such institutions. This particular section allows us to locate Polish military museums in the continuum of conceptual museum development. Later, we provide analysis of the nature of

\footnotetext{
${ }^{3}$ ARNOLD-DE SIMINE, Silke. Mediating memory in the museum. Trauma, empathy, nostalgia. Basingstoke: Palgrave Macmillan, 2013.

${ }^{4}$ KUHN, Thomas S. The Structure of Scientific Revolution. Chicago and London: The University of Chicago Press, 1962; MCGIMSEY, Charles Robert. Public archeology. New York-London: Seminar Press, 1972; LOWENTHAL, David. The Past is a Foreign Country. Cambridge: Cambridge University Press, 1985.

${ }^{5}$ PURCHLA, Jacek. Dziedzictwo kulturowe a kapitał społeczny [Cultural heritage and social capital]. In: Matopolskie Studia Regionalne, 1, 2011, p. 5-8. [In Polish]; MURZYN-KUPISZ, Monika. Dziedzictwo kulturowe a rozwój lokalny [Cultural heritage and local development]. Kraków: Wydawnictwo Uniwersytetu Ekonomicznego w Krakowie, 2012. [In Polish].

${ }^{6}$ RODELL, Dennis. Urban Conservation in the 1960s and 1970s: A European Overview. In: Architectural Heritage, 21:1, March 2011, p. 1-18; KLOSEK-KOZLOWSKA, Danuta. Dziedzictwo miast. Ochrona i rozwój [Heritage of the cities. Preservation and development]. Warszawa: Drukarnia Naukowa PAN, 2013. [In Polish]; KOWALSKI, Krzysztof. O istocie dziedzictwa europejskiego - rozważania [On the core of heritage - reflections]. Kraków: Międzynarodowe Centrum Kultury, 2013. [In Polish]; ASHWORTH, Gregory. Planowanie dzৃiedzictwa [Heritage planning]. Kraków: Międzynarodowe Centrum Kultury, 2015. [In Polish].
} 
war museums, focusing on the wide and complex character of their expositions, including conflicting and agonistic ones. The universal problems with interpretation of war heritage are also briefly discussed. The body of the paper presents the results of the surveys on Polish military museums. In order to capture the aforementioned ideological transition in museums we focused mainly on the ways expositions are constructed (traditional versus narrative approaches, cold and hot interpretation), the role of authentic monuments and modern tools of exposition in supporting or entirely building museum exhibition spaces, and the multiple scientific, social and market-driven functions of the museums under study. In light of these analyses, a categorization of the Polish war museums towards the "old" or "new" paradigms of the museum is presented and analysed.

In order to obtain these results, we used desk research methods supported by a questionnaire $^{7}$ (carried out on the basis of the procedure described below) and observation. We also provide an analysis of national literature on the subject, mainly in terms of resource size, character and changing trends in museology; analysis of international literature, in order to determine current trends in museology outside Poland; and analysis of source materials, including museums' official websites and a list of museum objects and sources/documents such as museum reports on participation in culture and the impact of culture on society. The literature reviews are enriched with the results of our own surveys, which served to verify previously adopted assumptions and described processes in Polish and international museology. The analysis of surveys is complemented by selected statistical methods.

\section{Changing concepts of the museum}

The tendency to accumulate objects seems to be an inherent feature of the human character. Collections, once gathered mainly by the wealthy or by group efforts, offered a tangible link with the past, a sign of wealth and social status, and, ultimately, helped to build a sense of community, to define what would distinguish one social group from another. "Social hierarchy inevitably leads to the appearance of a collection", 8 and collections often belong to the symbolic setting of authority and rituals accompanying the life of authorities. ${ }^{9}$ As Günay ${ }^{10}$ observes, ancient and medieval collections deposited in monasteries and universities were especially key to protecting the most valuable cultural works from destruction. While the Enlightenment owes its development in the field of knowledge and science to collecting, Romanticism brought interest in all that is strange, bizarre and abnormal, shown at fairs and in circuses, but also at freakshows. The passion for accumulating various types of collections, artefacts and peculiarities was fuelled by great geographical discoveries and civilizational progress, which triggered nostalgia for the traditional world that was becoming a thing of the past, sometimes during the lifespan of one generation. ${ }^{11}$ Some of the richest museum collections in the world were creat-

\footnotetext{
${ }^{7}$ The formulary of the questionnaire is included in the Appendix.

${ }^{8}$ POMIAN, Krzysztof. Zbieracze i osobliwości. Paryż-Wenecja XVI-XVIII w. [Collectors and curiosities. Paris-Venice the 16th-18th centuries]. Lublin: Wydawnictwo Uniwersytetu Marii Curie-Skłodowskiej, 2001. [In Polish] quoted in: POPCZYK, Maria. Estetyczne przestrzenie ekspozycji muzealnych [The aesthetic spaces of museum expositions]. Kraków: Wydawnictwo Universitas, 2008, p. 21. [In Polish].

${ }^{9}$ POPCZYK, Estetyczne....

${ }^{10}$ GÜNAY, Museum concept....

${ }^{11}$ GÜNAY, Museum concept....; URRY, John. Spojrzenie turysty [Tourist gaze]. Warszawa: PWN, 2007. [In Polish].
} 
ed during the colonial period. ${ }^{12}$ The development of European museum collections was also facilitated by wars and conquests in the turbulent political climate of the nineteenth century.

The significant development of museums in the nineteenth century also coincided with the search for and definition of the concept of "nation" and the enclosure of this concept by a series of sociocultural practices aimed at consolidating a community based on a common history, heritage and blood. As Ashworth has repeatedly written, "heritage" is a subjective category, socially and culturally constructed, a kind of collective "delusion". ${ }^{33}$ According to the author, this is probably the most important instrument for shaping territorial identity. The nation also identifies itself through links with the land of inhabits. Visiting places embodying a clearly defined collective memory of the "nation", including museums whose collections reflected the strategy of remembering and forgetting adopted by the community, made it possible to achieve the political and ideological goals of the nation-state. ${ }^{14}$ Heritage has been closed in museums not for aesthetic satisfaction or cultural enrichment; heritage accumulates power, authority and agency. ${ }^{15}$ Although the narrative of national museum collections was often based on a history heavily filtered by the needs of the present, ${ }^{16}$ visitors were offered a sense of belonging, community and uniqueness in relation to other groups. ${ }^{17}$ Museums certified as "national" were given special importance not only because of the uniqueness of their collections or their extraordinary volume, but also because of their far-reaching institutional and material care. Given the role of museums in shaping national identity, ${ }^{18}$ they can, like archives, be classified as "memorial sites" according to Pierre Nora's concept. ${ }^{19}$ Museums, treated as a kind of depository of what we want to call "heritage", serve to celebrate the past (or rather the imagination of it), while visiting them has become a kind of secular pilgrimage undertaken on

\footnotetext{
${ }^{12}$ MICHALIK, Magdalena. Instytucja muzeum, praktyka muzealna oraz muzealia w ujęciu teorii postkolonializmu - wstępne rozpoznanie [The institution of museum, museum practice and exhibits within the theory of postcolonialism - preliminary research]. In: Murealnictwo, 59, 2018, p. 28-33. [In Polish]. DOI: 10.5604/01.3001.0011.7254. ${ }^{13}$ ASHWORTH, Planowanie dziedzictwa, p. 13.

${ }^{14}$ KERN, Patrizia. Framing the Military-Nation: New War. Museums and Changing Representational Practices in Turkey since 2002. In: MUCHITSCH, Wolfgang (ed.) Does War Belong in Museums? The Representation of Violence in Exhibitions. Bielefeld: Verlag, 2013, p. 203-217; ZHANG, Carol X., XIAO, Honggen, MORGAN, Nigel, LY, Tuan Phong. Politics of memories: Identity construction in museums. In: Annals of Tourism Research, 73, 2018, p. 116-130. 15 "Heritage is about Power", ASHWORTH, Gregory. Pluralising the Past. Heritage Polices in Plural Societies. 2011 , p. 13. https://sites.eca.ed.ac.uk/ear/files/2011/11/EAR_30_2.pdf (accessed 10 October 2019).

${ }^{16}$ Ashworth, Graham and Tunbridge even write "heritage is present-centred and is created, shaped and managed by, and in response to, the demands of the presence." ASHWORTH, Gregory, GRAHAM, Brian, TUNBRIDGE, John. Pluralising Pasts. Heritage, Identity and Place in Multicultural Societies. London: Pluto Press, 2007, p. 3.

${ }^{17}$ FOUCAULT, Michel. The archaeology of knowledge and the discourse on language. New York: Pantheon Books, 1972 and WAKER, Rob. Postmodernism and nationalism. In: MOTYL, Alex. (ed.) Encyclopaedia of nationalism. San Diego: Academic Press, 2001, p. 611-630 quoted in: ZHANG et al. Politics of memories.

${ }^{18}$ The core of traditional museums is what we define subjectively as national heritage (see e.g. ASHWORTH, Planowanie dziedzictwa; DELAFONS, John. Politics and preservation: a policy bistory of the built heritage 1882-1996. London: Routledge, 1997. Some artefacts gain the status of historical monuments. Saryusz-Wolska writes about the role of cultural heritage and historical monuments in shaping the collective memory and identity of national communities, SARYUSZ-WOLSKA, Magdalena. Turystyka uwikłana w pamięć zbiorową [Tourism involved in collective memory]. In: Kultura Wspótczesna, 3, 2010, p. 63-74. [In Polish].

${ }_{19}$ NORA, Pierre. Les lieuxde Mémoire. Paris: Gallimard,1984. [n French]; NORA, Pierre. Between Memory and History: Les Lieux de Mémoire [Special Issue: Memory and Counter-Memory]. In: Representations, 26, Spring 1989, p. $7-24$.
} 
the basis of both our own tastes and patriotic duty. ${ }^{20}$ Due to the turbulent processes of shaping the political map of the nineteenth- and twentieth-century world, which generated numerous conflicts often resulting in the deaths of tens of thousands of people, the desire was born to commemorate the victims, to mourn the tragic death of the sons of the nation - or, in a more personal dimension, someone's sons, fathers, brothers - as well as to celebrate the heroism and sacrifice of the fighters or the genius of the commanders. ${ }^{21}$ For these reasons, not only battlefields and war cemeteries, but also museums reflecting the horrors of war, or celebrating military triumphs, tragic defeats and brilliant commanders, were visited. Some museums were created at the site of a historical event or in its vicinity, but more often they were built in central locations, determining the status of the state and nation.

The development of world (although first of all European) museology in the nineteenth century coincided with the great acceleration that took place in tourism at that time, owing to the invention of railways, which led to the democratisation and spread of travel as an attractive model of spending leisure time. Museums and tourism are positively linked, largely mutually conditioned phenomena. ${ }^{22}$ Museums as new, secular "places of worship" 23 require special, even ritualistic, behaviour from tourists. ${ }^{24}$ Famous museums such as the Louvre, Museo del Prado, the Hermitage or the British Museum are becoming a must-see for every mass tourist, even those not necessarily well-educated or particularly interested in culture.

An ancient collection, even an unusual and rich one, is a long way from the "museum" in the modern sense. We are talking about the latter, above all, when the exhibits do not only delight only the eye of the owner of the collection, but are collected with the aim of being made publicly and freely available, pursuing broad social, political and ideological objectives. This concept became popular in the aforementioned nineteenth century, the true "golden" era of museums, in which there appeared a rash of museums both in the Old and New World. ${ }^{25}$ However, the beginnings of this process date back to the eighteenth century and were sometimes violent. In France, it coincided with the Revolution, when, as Folga-Januszewska ${ }^{26}$ writes, "On the wave of 'freedom, equality and brotherhood', concepts of public collections as public property were created, as well as the first historical museums, where narration and the creation of a 'story' became a new form of presentation."

The second museum "boom" occurred after the Second World War. From the ruins that the war left behind, collections were built or reconstructed. The tragic events of the global conflict - mass extermination not only on the battlefield but also in bombarded cities, in concentration camps or as a result of the use of new deadly weapons (such as the atomic bomb used on Hiroshima and Nagasaki) - resulted in the creation of a new type of war museum with a pacifist message, commemorating the victims of collective cataclysms, but also condemning the war.

\footnotetext{
${ }^{20}$ However, visiting museums is induced by very extensive and varied motivations. See for instance: FALK, John Howard - DIERKING, Lynn Diane. The museum experience. Washington: Howells House, 1992.

${ }^{21}$ WHITMARSH, Andrew. We will remember them. Memory and commemoration in war museums. In: Journal of Conservation and Museum Studies, 7, November 2001, p. 1-15; WINTER, Caroline. The multiple roles of battlefield war museums: a study at Fromelles and Passchendaele. In: Journal of Heritage Tourism, 13:3, 2018, p. 211-223, DOI: 10.1080/1743873X.2017.1287189.

${ }^{22}$ HERREMAN, Museums and Tourism....

${ }^{23}$ FOLGA-JANUSZEWSKA, Dorota. Muzeologia, muzeografia, muzealnictwo [Museology, museaography, museum studies]. In: Murealnictwo, 47, 2006, p. 9-17. [In Polish].

${ }^{24}$ MACCANNELL, Dean. The Tourist: a new theory of the leisure class..New York: Schocken Books, 1976.

${ }^{25}$ See RICHARDS, Greg. (ed.) Cultural Tourism in Europe. Wallingford: CABI, 1996, p. 15-16.

${ }^{26}$ FOLGA-JANUSZEWSKA, Muzeologia..., p. 10.
} 
The phenomenon of the post-war museum boom was also rooted in the democratisation of culture, the growing importance of popular culture, the emergence of social groups with different expectations and preferences, and general globalisation. As Richards writes, museums could abandon the modernist project of universality in favour of market segmentation and theming. ${ }^{27}$ The political and sociocultural processes in the postcolonial and postmodern world, which gave an impulse for self-determination to increasingly diverse communities in ethnic, cultural and philosophical terms, were also not without significance for the creation of further museums. Indigenous peoples, ethnic minorities or communities marginalised for various reasons have regained their voice, along with the right to define their own heritage. Bezzeg also underlines that: "In addition to strengthening national identity, museums can also contribute to enhancing the consciousness of humanity as a species", ${ }^{28}$ pointing that, after all, we as humans share the same emotions, needs and desires. In the face of globalization, according to Young: "museums need to rethink their roles and objectives within new, relativist frames; and museums may find new representational roles as interpreters of cultural expressions both particular and universal". ${ }^{29}$ In other words, there is a need to connect local specificity with broader world contexts (also in relation to war museums). Technically, globalization in museums means a wide opportunity to exchange ideas, concepts, tools and skills, as well as high professional standards in terms of the collection of artefacts and their conservation, restoration, evaluation, preservation and exhibition. ${ }^{30}$

In terms of contemporary mass and global tourism development, Richards shows that among all cultural attractions, the number of museums has been growing the most rapidly, as has the competition they face, both among themselves and with other tourist attractions. ${ }^{31}$

Contemporary museology, represented, among others, by the International Council of $\mathrm{Mu}-$ seums (ICOM) and the legislation of many countries, understands the museum as "a permanent, non-profit institution, serving society and its development, accessible to the public, which conducts research on the evidence of human activity and human environment, collects, preserves, makes available and exhibits collections, carries out educational activities and serves entertainment". ${ }^{32}$ Although the tasks of a modern museum remain essentially the same, the way in which they are carried out has changed. Traditional museums, once treated as "guardians of the past", have evolved ${ }^{33}$ into modern educational centres whose aim is no longer simply to collect and present authentic, unique artefacts valuable from some strictly defined perspective, but to provide "centres for observation, learning and questioning". ${ }^{34}$ In other words, the museum has become a space for interpretation, and museums themselves have been transformed from

\footnotetext{
${ }^{27}$ RICHARDS, Cultural Tourism in Europe, p. 15.

${ }^{28}$ BEZZEG, Maria. The influence of globalisation on museology. In: International Journal of Heritage Studies, 5:1, 1999 , p. 20.

${ }^{29}$ YOUNG, Linda. Globalisation, culture and museums: A review of theory. In: International Journal of Heritage Studies, 5:1, 1999, p. 11.

${ }^{30}$ BEZZEG, The influence of globalisation...

${ }^{31}$ RICHARDS, Greg. Cultural Tourism. In: MCMANUS, Paulette. (ed.) Archaeological Displays and the Public. Museology and Interpretation (2nd edition). London: Routledge, 2016, p. 1-12.

${ }^{32}$ FOLGA-JANUSZEWSKA, Dorota. Muzeum: definicja i pojęcie. Czym jest muzeum dzisiaj? [The museum: definition and concept. What is a museum today?]. In: Murealnictwo, 49, 2008, p. 200. [In Polish].

${ }^{33}$ These changes resulted, among other things, from the reduction of financial resources allocated to the maintenance of museums (the need to attract more visitors as a source of additional income), as well as the need to adapt to the tastes of an increasingly mass visitor. Ibidem.

${ }^{34}$ GÜNAY, Museum concept..., p. 1255.
} 
places where culture and its products are shown into places where culture is created. Moreover, thanks to this ideological transformation, they are no longer perceived as elite, exclusive places for the sublime consumer. Petrunina ${ }^{35}$ also notices the broad and growing engagement of local communities, volunteers, collectors and "friends of the museum" societies in museums' activities, resulting in the transition of the static museum, focused on hoarding and protecting, into a social institution which is truly responsive to visitors' needs.

In Günay's ${ }^{36}$ opinion, contemporary museums are tools for mass culture. ${ }^{37}$ They are also (or should be) more and more participatory. ${ }^{38}$ As Jagodzińska writes,

More and more museums are focusing their attention on the viewer, and meeting their expectations and needs is becoming a priority for the management staff. The word 'spectator' frequently ceases to mean just a museum visitor. A visitor to the museum becomes a participant in museum activities, and even a co-creator of them. ${ }^{39}$

Although in practice the issue of museum participation is realised to varying degrees and in different ways depending on the nature of a given museum (for example, participation is eagerly used by institutions such as contemporary art museums or science centres), and although it is difficult to define its limits, the fact remains that museums are looking for new ways to conduct dialogue with the public or to get people more deeply involved.

Another noteworthy change in the contemporary museum industry is the replacement of the nineteenth-century "cult of the original" with the rush towards visualisation. As Folga-Januszewska ${ }^{40}$ notes, in many contemporary museums, "the process of replacing physical reality with the reality of reproduction has been greatly accelerated" and computer tools, animations, multimedia and interactive educational programs have become just as important (or perhaps more important?) as one's contact with the "real" exhibit. ${ }^{41}$ In accordance with the paradigm of interpretation, more and more museums are in fact focusing increasingly on narrative, on telling stories, rather than on objectively documenting reality. ${ }^{42}$ Interpretation is a keyword in contemporary museology (similarly to tourism). Its principles were defined by Tilden ${ }^{43}$ in 1957 in the classic work Interpreting Our Heritage. Understanding interpretation as art, Tilden emphasises the importance of referring to the personal or group experience of the visitors and the use of educational techniques and tools from various arts adapted to the intellectual and emotional capabilities of the audience (especially children). The interpretation is strongly based on information, but not on information alone. The exposition is rather a provocation, and in its

\footnotetext{
${ }^{35}$ PETRUNINA, Liubow. Museums: Towards the Social Institution. In: SMEDS, Kerstin (ed.) The Future of Tradition in Museology. Materials for a discussion. Paris: International Committee for Museology - ICOFOM, 2019, p. $133-137$. ${ }^{36}$ GÜNAY, Museum concept..., p. 1257.

${ }^{37}$ See: MORAWIŃSKA, Agnieszka. Rozszerzenie funkcji edukacyjnych współczesnego muzeum. [Expanding educational functions of the modern museum]. In: Kultura Wspótczesna, 3:37, 2003, p. 56-58. [In Polish].

${ }^{38}$ See: SIMON, Nina. The participatory museum. Santa Cruz: Museum, 2010.

${ }^{39}$ JAGODZIŃSKA, Katarzyna. Granice partycypacji w muzeum. [The limits for participation in a museum]. In: Murealnictwo, 57, 2016, p. 112. [In Polish].

${ }^{40}$ FOLGA-JANUSZEWSKA, Muzeum..., p. 201.

${ }^{41}$ The contact with the "authentic" exhibit is also understood differently in museums today. On the one hand, it does not always mean physical proximity - artefacts can become "tangible" in almost every detail through a virtual tour of the museum. On the other hand, visitors are able to shorten the distance between them and their heritage in "touchable museums" as much as possible, and are able to touch many exhibits, since the originals were replaced with replicas.

${ }^{42}$ FOLGA-JANUSZEWSKA, Muzeum....

${ }^{43}$ TILDEN, Freeman. Interpreting Our Heritage. Chapel Hill: The University of North Carolina Press, 1957.
} 
"hot" version it evokes an emotional response from the visitors. Uzzell, ${ }^{44}$ referring to the latter, writes that "Interpretation should be interesting, engaging, enjoyable, informative and entertaining. But now and again it has to be shocking, moving and provide a cathartic experience."

Among the many voices pointing to the transformations of contemporary museology on a global scale, there is no shortage of less optimistic or even critical ones. Clair ${ }^{45}$ points to the increasingly frequent phenomenon of the transformation of world museums into global brands on the same basis that real corporations governed by corporate laws are created. These processes are caused by museum commercialisation, museum marketing, museum franchises, branding and the global trading of museum exhibits. In extreme cases, the museum is already located somewhere between a "casino and a department store" and this problem is part of the wider phenomenon of cultural commodification. The phenomenon of expansion of the museum signalled by $\mathrm{Clair}^{46}$ takes place in many regions of the world. It largely concerns countries building a brand of luxury tourist destinations, but it is less threatening for countries such as Poland. ${ }^{47}$ Although the region of Central and Eastern Europe, especially after the fall of communism, fits in well with the post-war museum boom and has enormous potential in the context of the development of museum resources and the implementation of visionary ideas, it is still too weak economically to provide opportunities for the creation of domestic museum corporations to match the Western Europe ones.

\section{Military museums: definition, breakdown according to selected criteria}

In Polish legislation, Article 1 of the Museums Act ${ }^{48}$ stipulates that a museum is a non-profit organisational unit whose aim is to collect and permanently protect the natural and cultural heritage of humanity of material and non-material character; to inform about the values and contents of these collections; to disseminate the basic values of Polish and world history, science and culture; to shape cognitive and aesthetic sensitivity; and to make the collections available for use. The museums, which we will call "military" in our paper have in common either: 1) the directly military character of the collected exhibits (weapons, warfare equipment, military equipment and technology) or 2) the relationship of the presented exhibits to the history of war, the development of the art of war, defensive architecture, biographies of people involved in selected wars, both in practice and in general, at the theoretical level. These museums also include those whose collections or narrations focus on the semantic category of "war", show its material and spiritual consequences (including war cemeteries or in situ preserved places affected or completely destroyed by war), and explore its commemorative, affirmative, cautionary or pacifist meanings. Taking into account the classification of museum according to the type of collected museum exhibits, military museums fall into almost every commonly distinguished

\footnotetext{
${ }^{44}$ UZZELL, David. The Hot Interpretation of War and Conflict. In: UZZELL, David (ed.) Heritage Interpretation. Volume 1. The Natural and Built Environment. London, New York: Belhaven Press, 1989, p. 46.

${ }^{45}$ CLAIR, Jean. Kryzys muzeón: globalizacja kultury [Crisis of the museum: globalization of the culture]. Gdańsk: Wydawnictwo słowo/obraz terytoria, 2009 [in Polish] quoted in: JAGODZIŃSKA, Katarzyna. Ekspansja muzeów w Europie Środkowej? [Expansion of museums in Central Europe?]. In: RIHA Journal 0121, 3 June 2015. http:// www.riha-journal.org/articles/2015/2015-apr-jun/jagodzinska-ekspansja-muzeow-pl (accessed 10 October 2019). ${ }^{46}$ Ibidem.

${ }^{47}$ JAGODZIŃSKA, Ekspansja muzeów....

${ }^{48}$ Ustawa z dnia 21 listopada 1996 r. o muzeach. [The Act of 21 November 1996 on museums]. Dz. U. z 2012 r. poz. 987, z późn. zm. [In Polish].
} 
category of museums ${ }^{49}$ (Table 1). Military museums can be included in ten of the categories of museums distinguished by Lorentz, ${ }^{50}$ namely: museums/ monuments of combat and martyrdom, historical-military museums and collections, partially historical museums and collections, museums and collections of technical history, biographical museums and collections, maritime museum collections, palaces and castles, outdoor museums, memorial chambers and regional chambers.

In the scientific literature, military museums often appear under war museums, either dedicated to war in general or to selected conflicts. ${ }^{51}$ This is therefore a slightly narrower view of military museums than we use in this work. War museums are analysed primarily in a memorial context, where the main focus is on the commemoration of fallen soldiers or civilian victims. Among them, Holocaust museums or those dedicated to the mass extermination of selected human groups constitute a clearly distinguishable group. Museums created to oppose the war, although devoted to it, are usually called peace museums. ${ }^{52}$ Studies on the psychological and social foundations of commemoration, as well as forms, traditions and practices associated with them, including in museums, are widely represented in scientific literature. ${ }^{53}$

A museum, including a military museum, creates a kind of environment in which various rules of exhibiting and watching are practiced, where "conditions for the exchange of views are created, at the same time defining the scope of acceptable behaviours." 54 Military museums can function as: 1) traditional museum establishments where collections are accumulated, exhibited and made available. Sometimes, however, a museum is created 2) in situ, as in the case of defensive architecture, battlefields or war cemeteries. In such cases, the utility values of

\footnotetext{
${ }^{49}$ Categories of museums referred to in the reports on Polish museology prepared by The National Institute for Museums and Public Collections; see, for example, Muzea w 2017 roku. Statystyka muzeów. Warszawa: Narodowy Instytut Muzealnictwa i Ochrony Zbiorów, 2018. https://nimoz.pl/files/publications/55/Statystyka_muzeow_2017_online.pdf (accessed 10 October 2019). [In Polish].

${ }^{50}$ LORENTZ, Stanisław. Przewodnik po muzeach $i$ zbiorach $w$ Polsce. [Museums and collections in Poland Guidebook]. Warszawa: Wydawnictwa Interpress, 1982. [In Polish].

${ }^{51}$ See for instance: KERN, Framing the Military-Nation...

${ }^{52}$ TAMASHIRO, Roy, FURNARI, Ellen. Museums for peace: agents and instruments of peace education. In: Journal of Peace Education, 12:3, 2015, p. 223-235. http://dx.doi.org/10.1080/17400201.2015.1092712

${ }^{53}$ See e.g.: GAJDA, Kinga Anna. Muzeum jako nośnik pamięci. [Museum as a medium of memory]. In: DE ROSSET, Tomasz, BEDNARZ-DOICZMANOWA, Ewelina, TOLYSZ, Aldona (eds.) Muұeum a pamię́ - forma, produkcja, miejsce. Materialy konferencji zorganizowanej w dniach 8-9 czerwca 2017 roku przez. Zakład Muzealnictwa Wydzialu Sztuk Pięknych Uniwersytetu Mikotaja Kopernika w Toruniu. Warszawa: Narodowy Instytut Muzealnictwa i Ochrony Zbiorów, 2018, p. 73-81. [In Polish]; GREGORY, Adrian. The Silence of Memory: Armistice Day 1919-1946. Oxford: Berg, 1994; HIRSCHBERGER, Gilad, KENDE, Anna, WEINSTEIN, Shoshana. Defensive representations of an uncomfortable history: The case of Hungary and the Holocaust. In: International Journal of Intercultural Relations, 55, 2016, p. 32-43; KING, Alex. Memorials of the Great War in Britain: The Symbolism and Politics of Remembrance. Oxford: Berg, 1998; MOSSE, Georg. Fallen Soldiers: Reshaping the Memory of the World Wars. Oxford: Oxford University Press, 1990; WHITMARSH, We will remember them...; WINTER, Jay. Sites of Memory, Sites of Mourning: The Great War in European Cultural History. Cambridge: Cambridge University Press, 1995; and in Polish literature, among others, BRZEZIŃSKA, Anna, FABISZAK, Małgorzata, OWSIŃSKI, Marcin. (eds.) Znaki (nie)pamięci. Teoria i praktyka upamiętniania w Polsce. [Signs of oblivion. Theory and practice of commemoration in Poland]. Kraków: Universitas, 2016. [In Polish]; PARAFANOWICZ, Halina. Wojna i pamięć. Pierwsza wojna światowa i jej upamiętnianie przez Amerykanów. [War and memory. The Great War and its commemoration by the Americans]. In: Džieje Najnowsže, XLIX, 2017, p. 131-157. [In Polish]; WOŹNIAK, Michał. Muzeum - pamięć - miejsce pamięci. [Museum - memory site of memory]. In: DE ROSSET, Tomasz et al. (eds.) Muzeum a pamiéć-forma, produkecja, miejsce. Materiaty konferencji zorganizowanej w dniach 8-9 czerwca 2017 roku przez. Zakład Muzealnictwa Wydziału Sztuk Pieknych Uniwersytetu Mikołaja Kopernike w Toruniu. Warszawa: Narodowy Instytut Muzealnictwa i Ochrony Zbiorów, 2018, p. 22-30. [In Polish]. ${ }^{54}$ POPCZYK, Zbieracze i osobliwości..., p. 38.
} 
historic military objects, such as medieval castles or bastion fortresses, are used to display other historical-military artefacts or collections of different character, not always military. Due to the specificity of military collections, the formula of 3) the open air museum is often used; such places not only provide visitors with access to historical artefacts, but also act a backdrop for the events of so-called historical re-enactment. From here, we are getting close to the transition from a traditional museum to an amusement park.

\begin{tabular}{|c|c|c|c|c|c|c|c|c|c|}
\hline museum & 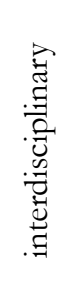 & 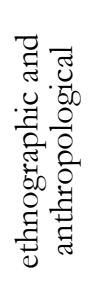 & 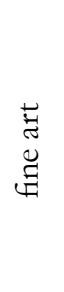 & 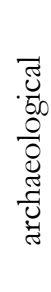 & 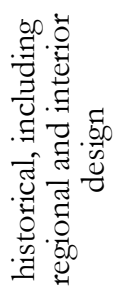 & 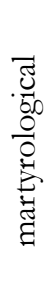 & 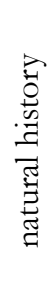 & 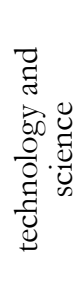 & 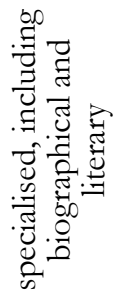 \\
\hline military & + & + & + & + & + & + & - & + & + \\
\hline
\end{tabular}

Tab. 1: Museums by type of exhibit and military museums among them, own study

Military museums, similarly to other categories of museums, may also be characterized according to many other categories (Table 2).

\begin{tabular}{|c|c|c|c|c|}
\hline & \multicolumn{4}{|c|}{ Criterion } \\
\hline \multirow[t]{7}{*}{ Museums } & $\begin{array}{l}\text { Character of the } \\
\text { operator }\end{array}$ & Structure & Physical form & Function \\
\hline & state & branch & material & educational \\
\hline & local government & \multirow[t]{5}{*}{ non-branch } & \multirow[t]{5}{*}{ virtual } & educational and cultural \\
\hline & $\begin{array}{l}\text { non-governmental } \\
\text { organisations }\end{array}$ & & & $\begin{array}{l}\text { educational, cultural and } \\
\text { entertainment }\end{array}$ \\
\hline & $\begin{array}{l}\text { organisational units } \\
\text { of a school or higher } \\
\text { education institution }\end{array}$ & & & \multirow[t]{3}{*}{ entertainment } \\
\hline & church organisations & & & \\
\hline & private & & & \\
\hline
\end{tabular}

Tab. 2: Types of museums according to their selected characteristics, own elaboration

Military museums, or museums with military exhibitions, are among the most widely represented type of museums in many countries of the world. ${ }^{55}$ Human history is a history of constant rivalry, often becoming an open war. These museums collect artefacts that prove victories, but also commemorate defeats, emphasising the heroism, devotion and moral superiority of the losers. Military museums are perfect as a tool for shaping the collective identity of nations, for preserving their collective memory; they represent the desire to arouse patriotic attitudes

\footnotetext{
${ }^{55}$ See for instance: TYTHACOT'T, Louise. Trophies of War: Representing 'Summer Palace' Loot in Military Museums in the UK. In: Museum \& Society, 13:4) November 2015, p. 469-488.
} 
as well as to manifest pride in belonging to a particular human community. Since wars are fought with complex weapons and other tools for attack or defence, military museums offer the opportunity to trace human technical genius and to admire the beauty of complex technical, engineering or constructional solutions. It is no coincidence that everything that is connected with warfare is called "ars militaris".

Due to the controversial nature of part of the collections (or military events which are commemorated from opposite and conflicting perspectives), military museums might be placed in the category of "dissonant heritage". ${ }^{56}$ The authors of this term, Tunbridge and Ashworth, ${ }^{57}$ simply refer to it as a heritage that can "hurt" and be a source of conflict. It is a controversial heritage, unwanted, denied or even destroyed and rejected by individuals or entire human groups. Examples include places associated with death, cruelty, guilt and unfair social practices (for example, slavery or racism). This category also includes the heritage of minorities, especially if they have been harmed (including genocide) by the majority, or "nobody's" heritage, a top-down name, with which none of the living identify. War belongs to the category of those who always carry death and destruction, both material and spiritual. It activates the worst features of human nature, it is a testimony to human imperfection. Therefore, it may seem controversial to collect objects created for the purpose of inflicting death, praising those who have mastered this art to perfection, measured by the number of triumphs on the battlefields and the number of dead, injured or mutilated. Every triumph is usually connected with someone's defeat, so it can be interpreted in a completely different way. Military museums or straightforward war museums usually present someone's point of view, someone's narrative, more often taking sides deliberately than unknowingly. Thus, a considerable proportion of war museums might be seen as "agonistic spaces" ${ }^{58}$ where the adopted way of interpreting the past may evoke mixed emotions. As Jarecka ${ }^{59}$ writes, even assuming the neutrality of the message, the factual and educational character of a warfare or military exhibition, through the selection of artefacts - complex, technically perfect, great, ingenious, sometimes simply beautiful - may in effect become a kind of affirmation of war. According to the author, such exhibitions emphasise the "beauty" of war, which is positively valorised as something that releases features such as courage, fraternity and solidarity in its participants. Moreover, with the increasing multimedia content of exhibitions, a wide range of exhibition tools or ways to engage visitors through various activities (e.g. through the possibility of virtually "shooting" historical weapons, transforming war into a role-playing video game, as in AK Museum in Kraków, Poland), a visit to a military museum becomes more of a fun and entertaining experience than an experience bringing deeper knowledge, increased empathy and reflection.

Creating exhibitions on the basis of war or military collections in military museums requires consideration of the problem of the purposeful aestheticization of such collections. As Pop$\operatorname{czyk}^{60}$ writes, "At the basis of all collecting lies aesthetics centred on the sense of sight." This

${ }^{56}$ REYNOLDS, Chris, BLAIR, William. Museums and 'Difficult Pasts': Northern Ireland's 1968. In: Museum International, 70:3-4. Special Issue: Museums \& Contested Histories, 2018, p. 12-25.

${ }^{57}$ TUNBRIDGE, John, ASHWORTH, Gregory. Dissonant Heritage: The Management of the Past as a Resource in Conflict. Chichester: Wiley, 1996.

${ }^{58}$ At least theoretically, see: CENTO BULL, Anna, LAUGE HANSEN, Hans, KANSTEINER, Wulf, PARISH, Nina. War museums as agonistic spaces: possibilities, opportunities and constraints. In: International Journal of Heritage Studies, 25:6, 2018, p. 611-625.

${ }^{59}$ JARECKA, Urszula. Turystyka patetyczna? Groza wojny jako atrakcja turystyczna. PPompous tourism? The terror of war as an attraction in tourist experience]. In: Kultura Wspótczesna, 3, 2010, p. 75-91. [In Polish].

${ }^{60}$ POPCZYK, Zbieracze i osobliwości..., p. 19. 
fact makes the collections appealing not only because of their merits, but also because of their visually attractive appearance. While admiring the beauty of the ancient melee weapons, illuminated, lying in elegant showcases, it is easy to forget that it was used primarily for killing, or that the well-tailored, elegant SS uniform was worn by members of one of the most criminal formations of the Second World War. Quoting Welsch, ${ }^{61}$ Popczyk emphasises that aesthetization leads to making reality unreal, beautifying various areas of human life and even creating "new" realities. Owing to aesthetization practices, war and everything connected with it becomes an intelligent hand, a game that requires equal cleverness and romantic bravado, equipped with visually attractive instruments. ${ }^{62}$ Likewise, while some military museums deliberately emanate death and horror, others, contrary to the tasks set by Uzzell ${ }^{63}$ for the interpretation of heritage, frequently portray a sanitised version of warfare. ${ }^{64}$ Paradoxically, in some cases, the pacifist message of exhibitions presented in military museums may also be controversial since, while focusing on the suffering of war victims, we forget about the perpetrators and their responsibility. Allen and Sakamoto ${ }^{65}$ write about this using the example of selected, less-known war museums in Japan. According to the authors, they focus on the suffering of the Japanese during the war and its personal costs, ignoring the perpetrators and the reasons why this tragic conflict took place.

Showakan and Shokeikan also share a discursive register about peace; they both point to the suffering of Japanese during the conflict and encourage a visitor to think about the personal cost of wars. Through understanding this pain and suffering, current generations will learn that war is bad; that all suffer in a war. The reasons for war remain silent. ${ }^{66}$

Contemporary geopolitics is not without significance for that which museums in general, and military museums in particular, commemorate and how they do so. Similarly, controversies around military museums are often related to the direction of narration ${ }^{67}$ or the choice of historical artefacts or media (photographs or films ${ }^{68}$ ), around which it is conducted. All this is connected with the question of who history belongs to and who has a greater right to tell it in their own words, according to the point of view shaped by book-bound knowledge or

\footnotetext{
${ }^{61}$ WELSCH, Wolfgang. Estetyka poza estetyką. O nowa postać estetyki. [Aesthetics beyond aesthetics. On a new shape of aesthetics]. Kraków: Wydawnictwo Universitas, 2005. [In Polish].

${ }^{62}$ REKDAL, Per. About the Beauty of War and the Attractivity of Violence. In: MUCHITSCH, Does War Belong in Museums?..., p. 123-130.

${ }^{63}$ The author puts it best in words: "Our museums and interpretative sites should be centres of excellence for telling the story of our cultural heritage in all its dimensions. Of course, we want them to be a celebration of the finest achievements of man, but if they are to be of educational value then they must also honestly represent the more shameful events of our past. To provoke an emotional response is not soft or weak. It is what it is to be human." UZZELL, The Hot Interpretation..., p. 46.

${ }^{64}$ WHITMARSH, We will remember them..., p. 2.

${ }^{65}$ ALLEN, Matthew, SAKAMOTO, Rumi. War and Peace: War Memories and Museums in Japan. In: History Compass, 11/12, 2013, p. 1047-1058. doi.10.1111/hic3.12108.

${ }^{66}$ Ibidem, p. 1054.

${ }^{67}$ CERCEL, Cristian, PARISH, Nina, ROWLEY, Eleanor. War in the Museum: The Historial of the Great War in Péronne and the Military History Museum in Dresden. In: Journal of War and Culture Studies, 12:2, May 2019, p. 194-214; SCOTT, James. Objects and the Representation of War in Military Museums. In: Museum \& Society, 13:4, 2015, p. 489-502; VERBYTSKA, Polina, KUZMYN, Roman. Between amnesia and the "war of memories": politics of memory in the museum narratives of Ukraine. In: Muzeológia a kultúrne dedičstvo, 7:2, 2019, p. 23-34.

${ }^{68}$ STYLIANOU-LAMBERT, Theopisti, BOUNIA, Alexandra. War Museums and Photography. In: Museum \& Society, 10:3, November 2012, p. 83-196.
} 
life experience. ${ }^{69}$ The museum might become here a real "conflict zone", a clash of different memories and ideologies. According to Dean, ${ }^{70}$ in the case of the Canadian War Museum and Bomber Command, the commemorative function of the museum (as a memorial site for the heroism and dedication of Canadian soldiers) triumphed over its educational objective:

Yet given past controversies, commemorative contexts, the Museum's history and its function as both a history museum and a site of memory, perhaps a display on the Allied bombing offensive that sought to do just that was always going to provoke controversy. This is a museum that combines the functions of a war memorial museum well, in its architecture, its design, and in the galleries where curator and veteran volunteers collaborate on a daily basis, but when differences did emerge it was perhaps inevitable that the museum as sacred site won over the museum as a trusted teacher. [Emphasis by the authors]

\section{Number and localisation of military museums in Poland}

The number of museums in Poland, including military museums, is not easy to establish (Table 3). There are large discrepancies between counts supplied by the institutions responsible for collecting statistics, web portals, thematic websites, reports and scientific publications. This may result from the application of different methodologies, taking into account or omitting museum departments and institutions in the organisation, as well as differences in the understanding of the scope of a museum (including a military-themed museum), as well as the inertia common to all lists and official registers in the face of changes in the number of museums over time. The total number of museums in Poland and the number of military museums, according to various sources, are presented in the Table 3.

\begin{tabular}{|c|c|c|c|}
\hline Source & Date & $\begin{array}{c}\text { Number of all } \\
\text { museums in Poland }\end{array}$ & $\begin{array}{c}\text { Number of military } \\
\text { museums in Poland }\end{array}$ \\
\hline $\begin{array}{c}\text { Guide to Museums and } \\
\text { Collections in Poland }\end{array}$ & 1982 & $\mathrm{x}$ & $\begin{array}{c}49 \text { (historical-military } \\
\text { museums and } \\
\text { collections) } \\
20 \text { (museums, } \\
\text { monuments to combat } \\
\text { and martyrdom) }\end{array}$ \\
\hline $\begin{array}{c}\text { Polish National Committee } \\
\text { of ICOM }\end{array}$ & 2013 & 1,050 & $\mathrm{x}$ \\
\hline $\begin{array}{c}\text { 1st Congress of Polish } \\
\text { Museologists }\end{array}$ & 2015 & 1,100 & $\mathrm{x}$ \\
\hline
\end{tabular}

\footnotetext{
${ }^{69}$ DEAN, David. Museums as conflict zones: The Canadian War Museum and Bomber Command. In: Museum \& Society, 7:1, March 2009, p. 1-15.

${ }^{70}$ Ibidem, p. 12.
} 
D. Chylińska, Ł. Musiaka: Military museums in Poland - between the past and the future

\begin{tabular}{|c|c|c|c|}
\hline Source & Date & $\begin{array}{c}\text { Number of all } \\
\text { museums in Poland }\end{array}$ & $\begin{array}{c}\text { Number of military } \\
\text { museums in Poland }\end{array}$ \\
\hline GUS report & 2016 & 944 & 55 \\
\hline $\begin{array}{c}\text { Wikipedia (according to } \\
\text { NIMOZ) }\end{array}$ & 2016 & 519 & 67 \\
\hline $\begin{array}{c}\text { NIMOZ (The National } \\
\text { Institute for Museums and } \\
\text { Public Collections) }\end{array}$ & 2017 & 1,027 & $\mathrm{x}$ \\
\hline $\begin{array}{c}\text { Ministry of Culture and } \\
\text { National Heritage }\end{array}$ & 2019 & 821 & $\mathrm{x}$ \\
\hline www.muzea.net & 2019 & 717 & 66 \\
\hline www.museo.pl & 2019 & 821 & 64 \\
\hline $\begin{array}{c}\text { Own research due to } \\
\text { Ministry of Culture and } \\
\text { National Heritage }\end{array}$ & 2019 & & \\
\hline
\end{tabular}

Tab. 3: Number of military museums in Poland due to different sources. Source: own research based on: NIMOZ (The National Institute for Museums and Public Collections), Polish National Committee of ICOM, data from 1st Congress of Polish Museologists in Lódź (23-25 April 2015), The GUS report (www.stat. gov.pl, accessed 21 June 2019), https://www.muzea.net/ portal (accessed 21 June 2019), https://www. museo.pl portal (accessed 21 June 2019), Wikipedia (accessed 21 June 2019), Ministry of Culture and National Heritage (http://bip.mkidn.gov.pl/pages/rejestry-ewidencje-archiwa-wykazy/rejestry-muzeow. php, accessed 22 June 2019), State Register of Museums and information on the status of the museum (http://bip.mkidn.gov.pl/pages/rejestry-ewidencje-archiwa-wykazy/rejestry-muzeow.php, accessed 23 September 2019), LORENTZ, Przewodnik po muzeach....

The final source of information which the authors decided to use in the paper was the list of museums published on the website of the Ministry of Culture and National Heritage. ${ }^{71}$ According to the data presented by the Ministry of Culture and National Heritage on 23 April 2019, there are 821 museums in Poland (without categories). ${ }^{72}$ The ministerial list contains data on museums which operate on the basis of statutes or regulations agreed with the minister in charge of culture and national heritage, pursuant to Article 6 of the Museums Act of 21 November 1996 (Journal of Laws of 2012 item 987 as amended). According to Article 5b of the Act, the list includes: the name of the museum; the address of the seat of the museum; the name of the entity that created the museum (in the case of a natural person - his or her name and surname, and in the case of a registered museum - the date of entry into the State Register

\footnotetext{
${ }^{71}$ http://bip.mkidn.gov.pl/pages/rejestry-ewidencje-archiwa-wykazy/rejestry-muzeow.php (accessed 22 June 2019 ).

72 The list contains data on museums which operate on the basis of statutes or regulations agreed with the minister in charge of culture and national heritage, pursuant to Article 6 of the Museums Act of 21 November 1996 (Journal of Laws 2012 item 987 as amended); http://bip.mkidn.gov.pl/pages/rejestry-ewidencje-archiwa-wykazy/ rejestry-muzeow.php (accessed 23 September 2019).
} 
of Museums); and information on the status of the museum. ${ }^{73}$

As for the numerical data on museum facilities in Poland in the literature on the subject, it should be stated that the authors of the works cited in the article provide data on the basis of the described ministerial and institutional sources. Comparatively, it is worth mentioning Lorentz's" ${ }^{74}$ work from nearly forty years ago entitled "Guide to Museums and Collections in Poland", where the author lists 49 museums classified as historical-military museums and collections, and 20 institutions classified as: museums, monuments to combat and martyrdom. Thus, the number of museums in Poland, including military museums, at the end of the twentieth and beginning of the twenty-first century is clearly growing.

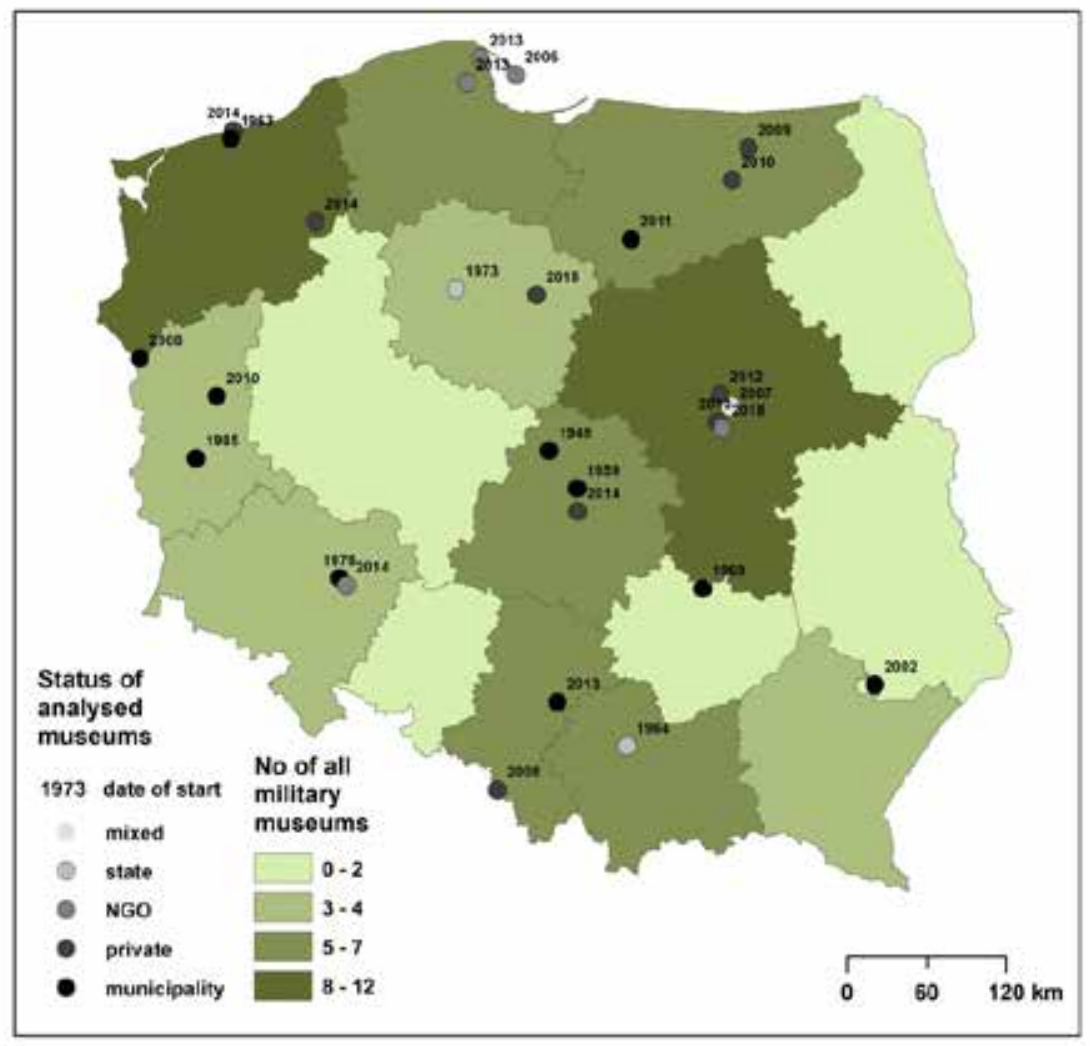

Figure 1: Analysed military museums according to dates of foundation and ownership compared to all military museums distinguished in Poland by voivodeships, own study

After the selection of a group of military museums, or museums that are at least partially military in character, the first step was to prepare a research tool in the form of an online questionnaire to be completed by the museums themselves. The questionnaire was sent to the e-mail addresses of all selected institutions or, in the absence of an e-mail, via a Facebook social networking account. Establishments with only a telephone number (single cases) were omitted from the study. Eight questionnaires were sent out in a test study and a small correc-

\footnotetext{
${ }^{73}$ http://bip.mkidn.gov.pl/pages/rejestry-ewidencje-archiwa-wykazy/rejestry-muzeow.php (accessed 23 September 2019).

${ }^{74}$ LORENTZ, Przewodnik po muzeach....
} 
tion of the test tool was made upon receipt of the first two replies. The main research period was from February to the end of March 2019, when questionnaires were sent to the remaining museums. The first completed questionnaire was received on 6 February and the last one on 20 March. If, seven days after sending the questionnaire, no reply had been received, the message was sent again. If there was still no answer after another week, a telephone call was made to request that the questionnaire be filled in. If this did not bring any results, further examination was abandoned. In this way, a total of 28 completed questionnaires were obtained and analysed.

The online survey had an extended form which can be divided into a demographic section and a main section. A total of fifty substantive (non-technical) questions were asked, both open, closed and semi-closed, including eight questions in the demographic section. The extensive questionnaire allowed the authors to collect rich research material, although its length may have had a negative impact on the number of returns received due to the time required to complete it $(4 \%$ of respondents completed the questionnaire within less than 10 minutes, $54 \%$ within $10-30$ minutes, $11 \%$ within $30-60$ minutes and $32 \%$ of the surveyed institutions within more than one hour). The authors tried to select the number and scope of questions in such a way as to reach a compromise between collecting the fullest possible research material and the comfort of people filling in the questionnaire on behalf of individual museums. The substantive questions concerned such issues as: the scope of activity of the museum, the size and character of collections, ways of presenting exhibits, promotion, planned and implemented investments and projects, and the size and structure of tourism. Due to the specific subject matter and scope of this article, only a part of the collected material has been analysed here.

Information collected as a result of the survey was first subjected to quantitative analysis, by adding up the answers to individual questions from all collected questionnaires. In the second phase we looked for correlations and links between the character of particular museums and the type of answers given. The third stage of analysis involved the development of conclusions from the research material and a critical comparison of these findings with the literature on the subject.

\section{Results}

As already mentioned, each of the institutions selected for the survey had an equal chance to be included in the survey. Unfortunately, the achieved return of questionnaires at the level of $26 \%$ of museums narrows to some extent the possibilities of inference. Some large, modern museums refused to cooperate (usually local-government ones, such as the Warsaw Uprising Museum, Emil Fieldorf "Nil" Home Army Museum in Cracow and the Museum of the Second World War in Gdańsk, subordinate to the Minister of Culture and National Heritage). Responses to questionnaires from these museums could perhaps have provided a better picture of some of the processes taking place in Polish museology in the last decade. Among the institutions that took part in the survey, more than half $(53 \%)$ are facilities run by private persons, foundations, associations and companies. Thus, market-oriented and visitor-centred establishments were more likely to respond. In the study, the most numerous museums were those of military equipment (64\%), followed by museums of battles, campaigns, uprisings and wars $(25 \%)$ and museums of military buildings and structures $(18 \%)$, while the least represented were biographical museums and museums of war (7\% each). The majority of museum exhibitions in the surveyed institutions were ordered thematically $(68 \%)$; less common were those ordered chronologically or historically (18\% each). The general narrative character of 
the museum exhibition was declared by $14 \%$ of museums, while the thematic character was reported by only $7 \%$. Almost all of the military museums surveyed ${ }^{75}$ build their exhibitions either solely $(52 \%)$ or partially $(44 \%)$ on the basis of authentic historic exhibits or monuments, the latter group offering replicas of historic objects and content presented on information boards or through multimedia alongside the original exhibits. In fewer than $4 \%$ of military museums, the museum space is constructed exclusively on the basis of replicas of monuments and exhibition tools in the form of information boards, multimedia displays and so on. The role of monuments in the studied military museums is therefore still dominant. Although in terms of the tools and means of exhibition used, military museums follow the latest trends in museology $(50 \%$ of museums use traditional means of exhibition enriched with multimedia boards and/or multimedia ${ }^{76}$ ), still almost one third of museums use a traditional "showcase" way of presenting the collected material. Among the establishments that support their exhibitions with multimedia exhibition tools (13 institutions), most use $2 \mathrm{D}$ film as the most popular medium (85\%), 46\% of museums use sound effects, and almost every fourth museum uses $2 \mathrm{D}$ multimedia presentations on an equal footing with the ones selected as frequently as multimedia applications ( $23 \%$ of the surveyed establishments each). Relatively rarely, museum workers use educational multimedia games or light effects (15\% each); however, $3 \mathrm{D}$ films or presentations and $360^{\circ}$ technology, turned out to be unused exhibition tools among the surveyed museums. $53 \%$ of all "multimedia" museums were established after 2000. Museums that are to some extent "multimedia" facilities also include museums of military equipment, museums of armed conflicts, museums of military units and formations, and museums of military buildings and structures.

The vast majority (75\%) of all surveyed military museums direct their offer to people of different ages, including children. Approximately $21 \%$ of museums target older audiences: young people and adults. None of these institutions, however, points to the controversial, child inappropriate or martyrological character of the collected artefacts, and their character also varies.

Not all museums are engaged in scientific activity; in fact, fewer than $40 \%$ of them are engaged in research. Those that do not conduct scientific research are almost entirely facilities established by private individuals or foundations (91\%); only one is a local government museum (Fig. 1). Scientific activities undertaken by museums usually involve activities relating to publishing, the participation of museum employees in (or organisation of their own) conferences, conducting fieldwork, archaeological studies or archival searches. A separate category is activities in the field of science communication, mainly popularising knowledge - for example, through public lectures - among children and young people. More than $65 \%$ of the surveyed military museums conduct commercial activities, including the sale of souvenirs (89\%) or scientific and popular science literature (89\%). Catering services are provided by every third museum. Thirty-eight per cent of these museums indicate other activities, the most frequently mentioned being the renting of commercial or historic space for all kinds of events (conferences, special events, photo wedding sessions or corporate events), and where the exhibitions include operational historic military vehicles, there are opportunities to organise trips.

The vast majority of museums collaborate with other such establishments (almost 86\%), most of which undertake cooperation of a scientific nature $(62 \%)$. Less than one in five of

\footnotetext{
${ }^{75}$ Out of 28 surveyed institutions, one did not answer the question about the share of authentic exhibits in the total museum exhibition.

${ }^{76}$ Of the 26 institutions that answered this question.
} 
the collaborating museums $(17 \%)$ do so in the field of promotion, also engaging with tourist organisations of various levels; $8 \%$ undertake multilateral cooperation in the field of education and training; and 12\% declare other, undefined forms of cooperation and collaborative partners.

The researched museums use a wide range of means and tools to promote their activity (Fig. 2) - from traditional analogue approaches (information leaflets were used in $71 \%$ of the establishments) to the latest digital ones, especially websites (61\%) and social media, such as Facebook, Twitter, Instagram or Snapchat (64\%).

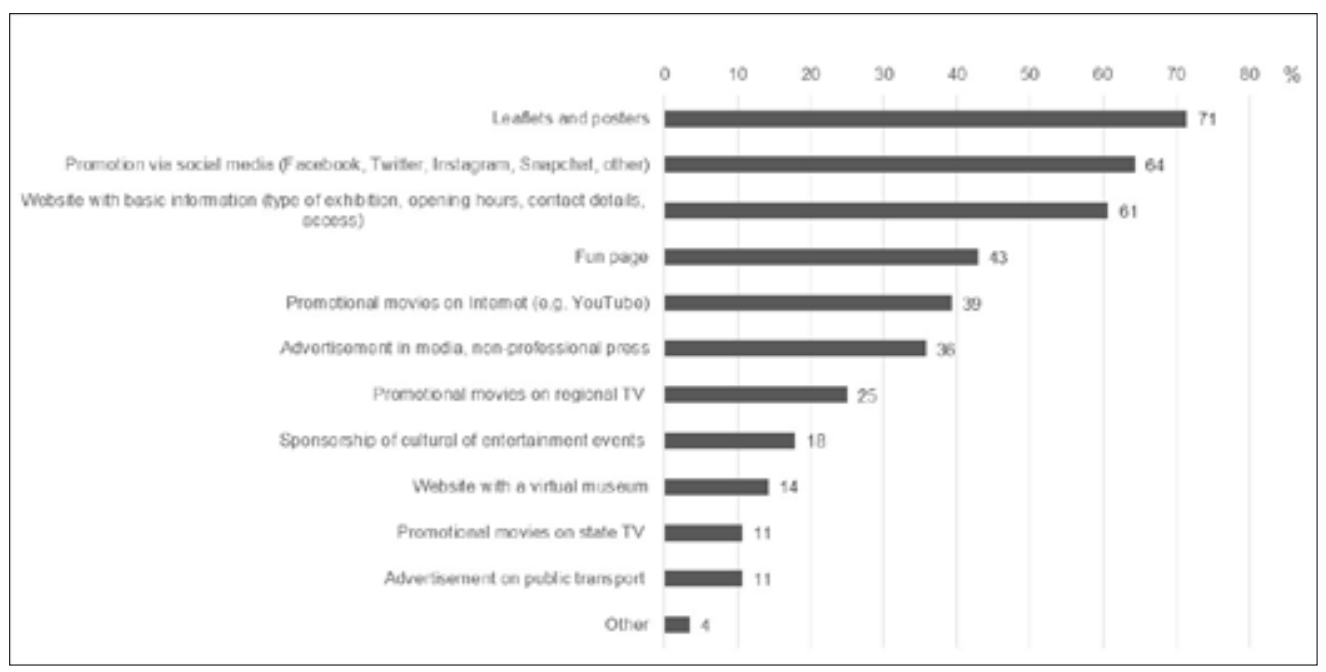

Fig. 2: Percentage share of museums using selected means and tools of promotion

Three quarters of the 24 museums that responded to the issue of public value declared that their exhibition shows the value of the collected exhibits (uniqueness, rarity, aesthetic values, etc.); the remaining museums indicated the more contextual nature of their exhibitions in illustrating wider historical, cultural, social or political phenomena by means of the collected exhibits. However, it is difficult to find any homogeneity in the latter group which would justify this approach to constructing a museum exhibition. A significant proportion of the surveyed museums - slightly over 64\% - use impersonal information messages focused on facts and the material characteristics of the collection items. Fewer than $3 \%$ use personalised narratives, combining objects with their manufacturers or selected human groups, or describing events through the biography of selected characters or human groups. This fact certainly explains the nature of most of the institutions surveyed, devoted more to historical objects than to the circumstances in which they were used. Every fourth museum described their exhibitions as having a mixed narrative character, depending on the character of the respective parts of the exhibition.

Table 3 shows the Pearson Contingency Coefficient (C) values for selected independent (first row from the top) and dependent (first column from the left) variables. The selection of variables resulted from the willingness to present the character of the activity of the studied museums and the way of asking questions in the questionnaire. The Pearson Contingency Coefficient $(\mathrm{C})$ applies to data of a qualitative nature and returns values in a range from 0 to 
1. Coefficients in the range from 0 to 0.3 characterise a very small correlation, those from 0.3 to 0.6 a moderate correlation and those above 0.6 a strong correlation. Using the presented method, we can only determine the intensity of correlation, without defining its direction and magnitude. For this reason, the analysis was enriched with additional factors not measured in the form of variables in Table 4.

\begin{tabular}{|l|c|c|c|c|}
\hline \multicolumn{1}{|c|}{$\begin{array}{c}\text { Independent } \\
\text { variables/dependant } \\
\text { variables }\end{array}$} & $\begin{array}{c}\text { Location } \\
\text { (urban/rural) }\end{array}$ & $\begin{array}{c}\text { Year of } \\
\text { foundation }\end{array}$ & $\begin{array}{c}\text { Founder/ } \\
\text { ownership } \\
\text { /management } \\
\text { of the } \\
\text { institution }\end{array}$ & $\begin{array}{c}\text { Military/non- } \\
\text { military facilities } \\
\text { headquarters of } \\
\text { the facility }\end{array}$ \\
\hline $\begin{array}{l}\text { Diversity of forms of } \\
\text { promotion }\end{array}$ & 0.40 & 0.44 & 0.49 & 0.28 \\
\hline $\begin{array}{l}\text { Conducting a } \\
\text { commercial offer }\end{array}$ & 0.31 & 0.46 & 0.48 & 0.19 \\
\hline $\begin{array}{l}\text { Carrying out scientific } \\
\text { activities }\end{array}$ & 0.33 & 0.43 & 0.52 & 0.10 \\
\hline $\begin{array}{l}\text { Multimedia/traditional } \\
\text { exhibition form }\end{array}$ & 0.37 & 0.27 & 0.24 & 0.06 \\
\hline $\begin{array}{l}\text { Narrow/wide } \\
\text { exhibition context }\end{array}$ & 0.22 & 0.11 & 0.33 & 0.06 \\
\hline
\end{tabular}

Tab. 4: Pearson Contingency Coefficient $(C)^{77}$ values for selected variables (the table shows corrected C values)

The variables whose impact on the nature of museum activity was statistically more significant were the institution's founder and its form of ownership/management and the year in which the museum was established. These independent variables had a major impact on the diversity of the forms of promotion used, the range of commercial services offered and the scientific activity carried out. In the case of the forms of promotion used, the most modest promotion was conducted in small, young establishments owned by private persons (enthusiasts), foundations or associations. The most extensive promotion was undertaken by military museums located in areas outside large cities which are relatively difficult to reach, and which are market-oriented in their activities and look for all possible ways to reach their potential customers/ visitors.

As far as the available commercial offer is concerned, such activities were not usually carried out by small, relatively new private museums run by history enthusiasts and focusing mainly on the exhibition, storage and provision of collections. Scientific activities were conducted mainly by older museums with a well-established market position and achievements, with adequate

\footnotetext{
${ }^{77} \mathrm{~A}$ measure to assess the relationship between two quality characteristics (non-measurable) $\mathrm{X}$ and $\mathrm{Y}$ when data are presented in the form of a quota table. This coefficient takes values from the range zero to one. A value of 0 means that the characteristics are independent and consequently uncorrelated. A value of 1 means a functional relationship. The coefficient does not indicate the direction of the relation. The value of the C-Pearson Contingency Coefficient depends on the size of the independence table, so in order to compare coefficients from different size tables it is necessary to normalize them. https://stat.gov.pl/ (accessed 5 August 2020).
} 
D. Chylińska, Ł. Musiaka: Military museums in Poland - between the past and the future

human resources and premises. These were mainly state and local government institutions, less often private ones or those run by foundations and associations.

\section{Discussion}

The collected material, although it came from only a quarter of the military museums in Poland, allows us to draw cautious conclusions about Polish military museums. Museums are one of the most important destinations of interest for heritage tourism, as evidenced, among other things, by the dynamic growth in the number of such facilities and the increase in the number of visitors, which can be treated as a reflection of the demand for such attractions. ${ }^{78}$ With the growing popularity of museums among visitors all over the world, museum workers face many problems related to the protection of collections or ensuring proper conditions of their use. ${ }^{79}$ Although, according to Krakowiak, ${ }^{80}$ military museums are not among the most popular type of institution, their number and, as we may assume, their popularity is growing. Polish military museums are a clear part of this phenomenon, which is confirmed by the fact that about $71 \%$ of the surveyed military museums were established after 2000, of which a fifth began in the last five years. Moreover, a search of all military museum objects showed up as many as 121 other museums "underway". Even if we assume that not all of these institutions will be created, this number confirms the continuing upward trend for museums with historical military themes. Moreover, the increase in the number of museums of a military nature is explained not only by the historical policy of the state, but also by the general commitment of society to creating an image of the past and the promotion of heritage, as expressed by the increase in the number of museums set up on the initiative of and run by private individuals or non-governmental foundations. The volume of the latter will increase even more, as evidenced by the survey conducted by the authors. Among the 121 museums in the process of organisation, only one is being established by a local government and two by the Ministry of Culture and National Heritage, the remainder are the responsibility of private individuals.

Referring to the research questions posed at the beginning of the article, it should be stated that the museums under our study are characterised by a kind of "cleavage", as if they were

\footnotetext{
${ }^{78}$ See, for example, FOLGA-JANUSZEWSKA, Dorota. Muzea w Polsce 1989-2008. [Museums in Poland 1989-2008]. In: Muzealnictwo, 50, 2009, p. 18-46. [In Polish]; MIKOS VON ROHRSCHEIDT, Armin. Polska: największe muzeum fortyfikacji na wolnym powietrzu w aspekcie rozwoju turystyki kulturowej [Poland: the biggest military open air museum in the view of cultural tourism development]. In: Turystyka Kulturowa, 2, 2009, p. $20-48$. [In Polish]; MIKOS VON ROHRSCHEIDT, Armin, JEDRYSIAK, Tadeusz. Militarna turystyka kulturowa. [Military cultural tourism]. Warszawa: Polskie Wydawnictwo Ekonomiczne, 2011. [In Polish]; MUSIAKA, Lukasz. Funkecja turystyczna średniowiecznych zamków i jej wplyw na miasta Pomorza, Warmii i Mazur. [The tourism function of the medieval castles of Pomerania, Warmia and Masuria]. Lódź: Wydawnictwo Uniwersytetu Lódzkiego, 2013. [In Polish]; MUSIAKA, Łukasz. Funkcja turystyczna zamków dawnego państwa krzyżackiego na przykładzie Malborka [The tourism function of the castles of the Knights of the Teutonic Order on the case of Malbork]. In: HOCHLEITNER, Janusz (ed.) Wyzwania turystyki kulturowej w Malborku. Malbork: Muzeum Zamkowe w Malborku, 2016, p. 23-42 [in Polish]; RICHARDS, Cultural Tourism in Europe; Uczestnictwo ludności w kulturze w 2014 roku. Warszawa: Główny Urząd Statystyczny, 2016. https://stat.gov.pl/obszary-tematyczne/kultura-turystyka-sport/kultura/uczestnictwo-ludnosci -w-kulturze-w-2014-r-,6,2.html (accessed 23 September 2019). [In Polish].

79 The urge to collect more exhibits and collections also means an increasing cost of their maintenance and the growing stock of "heritage" leads to an "accumulation crisis" (see e.g. MORGAN, Jennie. MACDONALD, Sharon. De-growing museum collections for new heritage futures. In: International Journal of Heritage Studies, 26:1, 2020, p. 56-70. doi: 10.1080/13527258.2018.1530289).

${ }^{80}$ KRAKOWIAK, Beata. Miejsce muzeów w turystyce kulturowej w Polsce. [The place of museums in cultural tourism in Poland]. In: Turyzm, 23:2, 2013, p. 23-33. [In Polish].
} 
simultaneously stuck in the old and new paradigms that define the concept of contemporary museology. They may be called museums in the times of change. On the one hand, these institutions fulfil one of the basic tasks of a museum - they collect and make available authentic exhibits - while on the other, they do not conduct scientific research, although they do cooperate with other institutions "of a scientific nature", as they call them. While the first circumstance, namely the "cult of the original", which comes straight from the nineteenth century but is supported to a large extent by modern interpretative tools (information boards, multimedia), places the studied Polish military museums somewhere between possible extremes, the fact that they do not carry out research or other scientific activity undermines the sense in which such institutions can be called "museums" in accordance with Polish legislation. ${ }^{81}$ Although in the survey the studied museums did not specify the reasons for such activity, it is somewhat puzzling that among institutions which do not carry out scientific activity, as many as $75 \%$ support themselves from their own or other activities (e.g. owners' own funds), whereas among those which carry out such activity, 54\% finance their activity mainly from subsidies and only $36 \%$ from their own or other sources.

When confronting the results of the survey with the contemporary trends in museology, some quite puzzling results draw our attention. It seems that they are in agreement with the general conclusions of Nieroba on Polish museology generally in the twenty-first century: namely that "the Polish museologist community does not fully embrace the ideas of New Museology" and "the status of the museum in the contemporary world seem to situate them closer to the traditional approach to the museum's social functions". ${ }^{82}$ These statements are based on the author's opinion that the economic and political circumstances in Poland simply differ from those present in the Western context, where the idea of abandoning the recipient's hegemonic subordination to the message conveyed by the museum was originally formed.

It should be noted that the researched museums are very slowly becoming part of the interpretation paradigm that is popular today, which is based on the narrative character of the museum's message and usually offers an objective and cold message of content (cold interpretation). As already mentioned, this fact can be partly explained by the nature of the institutions. Military equipment or militaria usually do not express emotions in themselves; they are also difficult to connect in an emotional and intriguing way with the people to whom they are connected (e.g. those who created them) or with the individual experiences of others (such as museum visitors). Therefore, it seems that the quintessence of the visit, at least in part among Polish military museums, is still more knowledge than experience. The results of the survey, however, confirm the gradual transformation of museums from educational institutions into "tourist attractions", places of broadly understood consumption, surrounded by other services that are not purely educational. This fact is also confirmed by the free use of many modern marketing tools that allow museums to reach potential consumers with their product offer. The question of whether the surveyed military museums are participatory in nature was outside the objectives of the survey, but the tourist has a partial possibility to shape his or her experience in them: more than half of the establishments (57\%) make their collections available either to visitors on their own or under the supervision of a guide; $14 \%$ do not offer guide services; and

\footnotetext{
${ }^{81}$ According to the Museums Act of 21 November 1996, Journal of Laws of 2012, Item 987, as amended, museums carry out their tasks through, among other things: cataloguing and scientific elaboration of accumulated collections, organising research and scientific expeditions, including archaeological ones, conducting publishing activities.

${ }^{82}$ NIEROBA, Elżbieta. National Museums and Museums of Modern Art in Poland - Competition for Domination in the Field of Museums. In: Muzeológia a kulturne dedićstvo, 6:2, 2018, p. 45-58, p. 56.
} 
about $17 \%$ of museums only provide guided tours. This, however, is only a substitute for the true participation of the viewer in a museum spectacle, ${ }^{83}$ but it does show that participatory museums have a broader raison d'être in contemporary facilities, which do not have to set boundaries and protect historic architectural objects. ${ }^{84}$

The results of research into military museums confirm the opinion of Jagodzińska ${ }^{85}$ on the lack of perspectives for the creation of strong and extensive museum corporations in Poland. Sixty-four per cent of the museums are independent: that is, they are neither subsidiaries of any other institution nor have branches themselves. It is interesting to note that some of the museums which conduct their operations within an external structure indicate membership of the Association of Private Polish Museum Collectors, which was registered in $2016^{86}$ and which aims to represent and lobby for the community of private museum creators deprived of economic support from the state, based on the provisions of the Museums Act (Journal of Laws of 2012 item 987 as amended). The fact that among the 46 members of the association, ${ }^{87}$ over $76 \%$ of private museums have a historical-military character confirms that museums presenting this kind of subject matter are part of the museum boom phenomenon of the twenty-first century in Poland. Jagodzińska ${ }^{88}$ goes so far as to call this phenomenon in Poland "museum overproduction" or even refer to it as a "museum factory".

The museums that responded to the question on the origin of visitors were seeing a clear majority of domestic visitors ( $80 \%$ or more) in their overall footfall. Only three institutions declared that domestic and foreign guests were visiting in a ratio of approximately $2: 1$, and these were all located in close proximity to the Polish-German border, at a seaside summer resort popular among foreign tourists. The predominance of domestic traffic in most of the surveyed museums is not surprising, as most of them are of a regional or local rank, often located far from large tourist centres, suggesting that sightseeing options or other tourist attractions are important from the point-of-view of foreign tourism. Are the surveyed museums therefore an attractive offer only in the market of domestic museum attractions? In light of the research, it seems that they are located somewhere in the middle of the scale between locality and universality. As described above, most institutions focus on the presentation of the objective values of the military exhibits (uniqueness, technical thought, antiquity and so on) and thus meet the conditions of universality. The specific "beauty" or technological thought behind the creation of the T-34 tank or melee weapons and firearms from different epochs will interest the viewer regardless of their cultural or national roots. Nevertheless, as in other parts of the world, the museums studied contain artefacts that are important not for these objective features, but for the local national context, not always obvious or understandable to the outside world. In the collections of the studied museums we can find, for example, a PZL P.11c plane which took part in the September 1939 campaign (according to the museum itself) and, as the only surviving specimen of this type of aircraft, is considered to be the most valuable exhibit of the Museum of Polish Aviation.

\footnotetext{
${ }^{83}$ SIMON, The participatory museum....

${ }^{84}$ JAGODZIŃSKA, Granice partycypacji w muzeum...

${ }^{85}$ JAGODZIŃSKA, Ekspansja muzeów....

${ }_{86}$ This institution continued the tasks of an earlier foundation, "Eksponat".

${ }^{87}$ As of 31 May 2019, http://prywatnemuzea.pl/muzea-zrzeszone.

${ }^{88}$ JAGODZIŃSKA, Katarzyna. Muzealna nadprodukcja? [Museum overproduction?]. In: Muzealnictwo, 52, 2011, p. 215-225. [In Polish].
} 


\section{Conclusions}

As a summary of the proper analysis of the results of research on military museums in Poland, the authors propose to separate the studied museums into three characteristic groups according to selected characteristics of their activity and the nature of the exhibition:

1. Small museums, established over the last $10-15$ years, run by private individuals, foundations or associations, with small floorspace, a low number of exhibits and usually run by one person. These museums tend to be focused on traditional forms of exhibiting their collections, largely consisting of original objects, without multimedia or a broader historical narrative, presenting the value of collections/monuments "in themselves". They do not conduct any scientific activity, do not have any commercial offer, and their promotional measures can be described as modest. Such establishments are not aimed at generating the highest possible profit.

2. Institutions established 10-15 years ago, but also older ones, with more extensive premises, a wide commercial offer and a very extensive promotional apparatus. They have significant floorspace and a larger number of exhibits or additional attractions, offering relatively high levels of multimedia in their exhibitions. The narrative of the exposition often has a broader historical character. Such facilities are largely geared towards mass tourism, mainly children's groups. They have a clear market orientation. They do not carry out scientific activities to any great extent.

3. Museums with an established position which have been operating for several dozen years, located in cities. Usually established by local governments or state institutions. Such museums have a large number of exhibits, sometimes including very valuable collections. In terms of human resources, staffing levels tend to be high, allowing them to carry out scientific research. Promotional activities are carried out dynamically, but to a lesser extent than in museums in the second group. The museum's advertising and brand are often positively influenced by the historic character of its premises. Museums classified in the third group use multimedia devices to a significant degree and the narration of the collections is very often broad. These establishments are characterised by a moderate focus on commercial activities.

It is impossible to discuss all the topics concerning military museums in Poland within the framework of an article, but it is worth mentioning in the summary those that testify to the Polish specificity of this segment of cultural heritage and, at the same time, the tourist product. According to the authors, the situation of the central (main) Polish Army Museum in Warsaw may serve as a certain symbol of the current qualitative changes in Polish military museums. It is the largest museum institution in Poland with a military profile (over 250 thousand exhibits). The vast majority of the institution is given over to exhibitions which, due to the period of their creation (in the times of the People's Republic of Poland) do not conform to modern standards or the requirements of a modern museum. In 2018, a tender for a general contractor for the construction of a new facility, together with a modern display of forms of communication, was completed. ${ }^{89}$ The new facility, which cost over PLN 250 million to build, has a chance to set new standards and canons concerning the form and manner of museum narration in Poland.

Another trend in Polish museology visible in recent years is the attempt to describe some events from the past anew. This movement is primarily about bringing to light and preserving in the form of a museum exhibition those events, people and conflicts that have, for political reasons, been neglected in scientific research, education, media and public discourse in Poland,

${ }^{89}$ http://www.muzeumwp.pl/ (accessed 17 September 2019). 
especially during the period 1945-1989. History is the mother of politics, and newly emerging museums - such as the Warsaw Uprising Museum (2004), the Museum of the Second World War in Gdańsk (2017), or the Westerplatte and War 1939 Museum, which opened on 1 September 2019 (the $80^{\text {th }}$ anniversary of the outbreak of World War II) - show the need to verify, update and, above all, disseminate knowledge about the most difficult moments in Polish history and the tragedy of armed conflicts. ${ }^{90}$ Both situations described above are, to a large extent, determined by the twentieth-century history of the country, and can be applied to other museums in Poland (including those studied by the authors).

Looking for generalisations, it is worth noting that the example of Polish military museums also clearly illustrates just how far museums in the world have evolved from their origins to the present day. Nowadays, museums, in order to increase their attractiveness and adapt to an increasingly technologically oriented world and the rise of image culture in society, focus more and more on participation, interactivity and multimedia. They are inevitably heading towards the amusement park paradigm rather than representing respectable cultural institutions. It would seem that the message from museums, including military ones, is being simplified and trivialised. However, the growing role of some museums as powerful tools for shaping historical policy and representing the interests of states, nations and communities contradicts such a one-sided assessment. And in this field, military museums are probably among the most important.

In the technical dimension and the form of exhibition, we can observe a dynamic pursuit of modernity in the message and an attempt to fight for customers. Owners of the largest and richest museums observe world trends and try to follow them. Museums are increasingly becoming economic entities operating in the tourism market. This also applies to institutions established by local authorities or the state. As for issues related not to the form but to the content of Polish military museums, we can also observe an interesting phenomenon: namely, a specific attempt at making up for the lost time of the Communist period. During this period, history was hypocritical due to its one-sided political orientation towards the USSR; certain facts and events that were inconvenient for the Communist authorities were simply not allowed to be spoken about. An attempt to rectify the legacy of the years $1945-1989$ is connected with the contemporary educational mission of museums. This mission is addressed both to domestic and, increasingly often, to foreign audiences. This is particularly visible in the context of defining the role and significance of Poland in the Second World War. Since Poland, following its social and economic transformation at the beginning of the 1990s, returned to the family of democratic states, there has been no shortage of media examples of disinformation, lack of knowledge and attempts at presenting Poles as co-perpetrators of the Second World War. After 1989, Polish military museums faced an opportunity to tell a story without the form and content of the message imposed from above. However, answering the question whether they have taken advantage of this opportunity is not the aim of this study, although it does, of course, create a broad and difficult field for further analysis and research in many respects.

${ }_{90}^{90 w w .1944 . p l ; ~ m u s e u m 1939 . p l ~(a c c e s s e d ~} 3$ October 2019). 


\section{References}

ALLEN, Matthew, SAKAMOTO, Rumi (2013). War and Peace: War Memories and Museums in Japan. In: History Compass, 11/12, p. 1047-1058. doi.10.1111/hic3.12108. ISSN 14780542.

ARNOLD-DE SIMINE, Silke (2013). Mediating memory in the museum. Trauma, empathy, nostalgia. Basingstoke: Palgrave Macmillan. ISBN: 978-0230368866.

ASHWORTH, Gregory, GRAHAM, Brian, TUNBRIDGE, John (2007). Pluralising Pasts. Heritage, Identity and Place in Multicultural Societies. London: Pluto Press. ISBN: 978-0745322858.

ASHWORTH, Gregory (2011). Pluralising the Past. Heritage Polices in Plural Societies. https:// sites. eca.ed.ac.uk/ear/files/2011/11/EAR_30_2.pdf (accessed 10 October 2019).

ASHWORTH, Gregory (2015). Planowanie dżiedzictwa [Heritage planning]. Kraków: Międzynarodowe Centrum Kultury. [n Polish]. ISBN 978-83-63463-34-2.

BEZZEG, Maria (1999). The influence of globalisation on museology. In: International Journal of Heritage Studies, 5:1, p. 16-20, doi.10.1080/13527259908722243. ISSN: 1470-3610

BRZEZIŃSKA, Anna, FABISZAK, Małgorzata - OWSIŃSKI, Marcin (eds.) (2016). Znaki (nie)pamieci. Teoria i praktyka upamiętniania w Polsce. [Signs of oblivion. Theory and practice of commemoration in Poland]. Kraków: Universitas. [In Polish]. ISBN: 97883-242-3076-1.

CENTO BULL, Anna, LAUGE HANSEN, Hans, KANSTEINER, Wulf, PARISH, Nina (2018). War museums as agonistic spaces: possibilities, opportunities and constraints. In: International Journal of Heritage Studies, 25:6, p. 611-625. ISSN: [1352-7258.

CERCEL, Cristian, PARISH, Nina, ROWLEY, Eleanor (May 2019). War in the Museum: The Historial of the Great War in Péronne and the Military History Museum in Dresden. In: Journal of War and Culture Studies, 12:2, p. 194-214. ISSN: 1752-6272.

CLAIR, Jean (2009). Kryzys muzeów: globalizacja kultury [Crisis of the museum: globalization of the culture]. Gdańsk: Wydawnictwo słowo/obraz terytoria. [In Polish]. ISBN: 978-837453-902-9

DEAN, David (March 2009). Museums as conflict zones: The Canadian War Museum and Bomber Command. In: Museum \& Society, 7:1, p. 1-15. ISSN 1479-8360.

DELAFONS, John (1997). Politics and preservation: a policy history of the built heritage 1882-1996. London: Routledge. ISBN-13: 978-0419224006.

FALK, John Howard, DIERKING, Lynn Diane (1992). The museum experience. Washington: Howells House. ISBN 10: 0929590074

FOLGA-JANUSZEWSKA, Dorota (2006). Muzeologia, muzeografia, muzealnictwo [Museology, museaography, museum studies]. In: Muzealnictwo, 47, p. 9-17. [In Polish]. ISSN: 04641086.

FOLGA-JANUSZEWSKA, Dorota (2008). Muzeum: definicja i pojęcie. Czym jest muzeum dzisiaj? [The museum: definition and concept. What is a museum today?]. In: Muzealnictwo, 49, p. 200-203. [In Polish]. ISSN: 0464-1086.

FOLGA-JANUSZEWSKA, Dorota (2009). Muzea w Polsce 1989-2008. [Museums in Poland 1989-2008]. In: Murealnictwo, 50, p. 18-46. [In Polish]. ISSN: 0464-1086.

FOUCAULT, Michel (1972). The archaeology of knowledge and the discourse on language. New York: Pantheon Books. ISBN: 978-0394711065. 
GAJDA, Kinga Anna (2018). Muzeum jako nośnik pamięci. [Museum as a medium of memory]. In: DE ROSSET, Tomasz, BEDNARZ-DOICZMANOWA, Ewelina, TOEYSZ, Aldona (eds.) Muzeum a pamieć - forma, produkcja, miejsce. Materiaty konferencji zorganizowanej w dniach 8-9 czerwca 2017 roku pręez Zaktad Muzealnictwa Wydziatu Sztuk Pieknych Uniwersytetu Mikotaja Kopernika w Toruniu. Warszawa: Narodowy Instytut Muzealnictwa i Ochrony Zbiorów, p. 73-81. ISBN 978-83-64889-31-8.

GREGORY, Adrian (1994). The Silence of Memory: Armistice Day 1919-1946. Oxford: Berg. ISBN: 9781859730010.

GÜNAY, Burcu (2012). Museum concept from past to present and importance of museums as centers of art education. In: Procedia - Social and Behavioral Sciences, 55, p. 1250-1258. ISSN: 1877-0428.

HERREMAN, Yani (July-September 1998). Museums and Tourism: Culture and Consumption. In: Museum International, 50:3, p. 2-64. Online ISSN:1468-0033.

HIRSCHBERGER, Gilad - KENDE, Anna - WEINSTEIN, Shoshana (2016). Defensive representations of an uncomfortable history: The case of Hungary and the Holocaust. In: International Journal of Intercultural Relations, 55, p. 32-43. ISSN: 0147-1767.

JAGODZINSKA, Katarzyna (2016). Granice partycypacji w muzeum. [The limits for participation in a museum]. In: Murealnictwo, 57, p. 112-121. [In Polish]. ISSN: 0464-1086.

JAGODZIŃSKA, Katarzyna (June 2015). Ekspansja muzeów w Europie Środkowej? [Expansion of museums in Central Europe?]. In: RIHA Journal 0121. http:/ / www.riha-journal.org/ articles/2015/2015-apr-jun/jagodzinska-ekspansja-muzeow-pl (accessed 10 October 2019). ISSN: $2190-3328$.

JAGODZIŃSKA, Katarzyna (2011). Muzealna nadprodukcja? [Museum overproduction?]. In: Murealnictwo, 52, p. 215-225. [In Polish]. ISSN: 0464-1086.

JARECKA, Urszula (2010). Turystyka patetyczna? Groza wojny jako atrakcja turystyczna. [Pompous tourism? The terror of war as an attraction in tourist experience]. In: Kultura Wspótczesna, 3, p. 75-91. [In Polish]. ISSN 2300-1704.

KERN, Patrizia (2013). Framing the Military-Nation: New War. Museums and Changing Representational Practices in Turkey since 2002. In: MUCHITSCH, Wolfgang (ed.) Does War Belong in Museums? The Representation of Violence in Exhibitions. Bielefeld: Verlag, p. 203-217. PDF-ISBN 978-3-8394-2306-6.

KING, Alex (1998). Memorials of the Great War in Britain: The Symbolism and Politics of Remembrance. Oxford: Berg. ISBN: 978-1859739884.

KŁOSEK-KOZLOWSKA, Danuta (2013). Dziedzictwo miast. Ochrona i rozwój [Heritage of the cities. Preservation and development]. Warszawa: Drukarnia Naukowa PAN. [In Polish]. ISBN 978-83-61236-45-0

KOWALSKI, Krzysztof (2013). O istocie dziedzictwa europejskiego - rozważania [On the core of heritage - reflections]. Kraków: Międzynarodowe Centrum Kultury. [In Polish]. ISBN 97883-63463-11-3.

KRAKOWIAK, Beata (2013). Miejsce muzeów w turystyce kulturowej w Polsce. [The place of museums in cultural tourism in Poland]. In: Tury:m, 23:2, p. 23-33. [In Polish]. ISSN 2080-6922.

KUHN, Thomas S. (1962). The Structure of Scientific Revolution. Chicago and London: The University of Chicago Press. ISBN: 978-0226458083. 
LORENTZ, Stanisław (1982). Przewodnik po muzeach $i$ zbiorach w Polsce. [Museums and collections in Poland Guidebook]. Warszawa: Wydawnictwa Interpress. [In Polish]. ISBN 83-2231936-3.

LOWENTHAL, David (1985). The Past is a Foreign Country. Cambridge: Cambridge University Press. ISBN: 978-0521294805.

MACCANNELL, Dean (1976). The Tourist: a new theory of the leisure class. New York: Schocken Books. ISBN: 9780520280007.

MARSTINE, Janet (2006). Introduction. In: MARSTINE, Janet (ed.) New Museum Theory and Practice. An Introduction. Oxford: Blackwell Publishing, p. 1-36. ISBN: 978-1405105590.

MCGIMSEY, Charles Robert (1972). Public archeology. New York-London: Seminar Press. ISBN: 978-0128724507.

MICHALIK, Magdalena (2018). Instytucja muzeum, praktyka muzealna oraz muzealia w ujęciu teorii postkolonializmu - wstępne rozpoznanie [The institution of museum, museum practice and exhibits within the theory of postcolonialism - preliminary research]. In: Muzealnictwo, 59, p. 28-33. [In Polish]. DOI: 10.5604/01.3001.0011.7254. ISSN: 0464-1086.

MIKOS VON ROHRSCHEIDT, Armin, JEDDRYSIAK, Tadeusz (2011). Militarna turystyka kulturowa. [Military cultural tourism]. Warszawa: Polskie Wydawnictwo Ekonomiczne. [In Polish]. ISBN: 978-83-208-1952-6

MIKOS VON ROHRSCHEIDT, Armin (2009). Polska: największe muzeum fortyfikacji na wolnym powietrzu w aspekcie rozwoju turystyki kulturowej [Poland: the biggest military open-air museum in the view of cultural tourism development]. In: Turystyka Kulturowa, 2, p. 20-48. ISSN: $1689-4642$.

MORAWIŃSKA, Agnieszka (2003). Rozszerzenie funkcji edukacyjnych współczesnego muzeum. [Expanding educational functions of modern museum]. In: Kultura Współczesna, 3:37, p. $56-58$. ISSN $2300-1704$.

MORGAN, Jennie, MACDONALD, Sharon (2020). De-growing museum collections for new heritage futures. In: International Journal of Heritage Studies, 26:1, p. 56-70. DOI: 10.1080/13527258.2018.1530289. ISSN:1352-7258.

MOSSE, Georg (1990). Fallen Soldiers: Reshaping the Memory of the World Wars. Oxford: Oxford University Press. ISBN: 978-0195071399.

MURZYN-KUPISZ, Monika (2012). Dziedzictwo kulturowe a rozwój lokalny [Cultural heritage and local development]. Kraków: Wydawnictwo Uniwersytetu Ekonomicznego w Krakowie. [In Polish]. ISBN 978-83-7252-609-0.

MUSIAKA, Lukasz (2013). Funkcja turystyczna średniowiecznych zamków i jej wplyw na miasta Pomorza, Warmii i Mazur. [The tourism function of the medieval castles of Pomerania, Warmia and Masuria]. Łódź: Wydawnictwo Uniwersytetu Lódzkiego. [In Polish]. ISBN: 978-837969-001-5.

MUSIAKA, Łukasz (2016). Funkcja turystyczna zamków dawnego państwa krzyżackiego na przykładzie Malborka [The tourism function of the castles of the Knights of the Teutonic Order on the case of Malbork]. In: HOCHLEITNER, Janusz (Ed.) Wyzwania turystyki kulturowej w Malborku. Malbork: Muzeum Zamkowe w Malborku, p. 23-42. [In Polish]. ISBN 978-83-60518-83-0.

Muzea w 2017 roku. Statystyka muzeów. Warszawa: Narodowy Instytut Muzealnictwa i Ochrony Zbiorów, 2018. https://nimoz.pl/files/publications/55/Statystyka_muzeow_2017_online. pdf (accessed 10 October 2019). [In Polish]. 
NIEROBA, Elżbieta (2018). National Museums and Museums of Modern Art in Poland Competition for Domination in the Field of Museums. In: Muzeológia a kulturne dedičstvo, 6:2, p. 45-58. ISSN: 2453-9759 (Online).

NORA, Pierre (1984). Les lieuxde Mémoire. Paris: Gallimard. [In French]. ISBN: 978-2070701926.

NORA, Pierre (Spring 1989). Between Memory and History: Les Lieux de Mémoire [Special Issue: Memory and Counter-Memory]. In: Representations, 26, p. 7-24. ISSN 1533-855X.

PARAFANOWICZ, Halina (2017). Wojna i pamięć. Pierwsza wojna światowa i jej upamiętnianie przez Amerykanów. [War and memory. The Great War and its commemoration by the Americans]. In: Drieje Najnowsze, XLIX, p. 131-157. [In Polish]. ISSN online 2451-1323.

PETRUNINA, Liubow (2019). Museums: Towards the Social Institution. In: SMEDS, Kerstin (ed.) The Future of Tradition in Museology. Materials for a discussion. Paris: International Committee for Museology - ICOFOM, p. 133-137. ISBN: 978-92-9012-466-5.

POMIAN, Krzysztof (2001). Zbieracze i osobliwości. Paryż-Wenecja XVI-XVIII w. [Collectors and curiosities. Paris-Venice the 16th-18th centuries]. Lublin: Wydawnictwo Uniwersytetu Marii Curie-Skłodowskiej. [In Polish]. ISBN: 83-227-1764-4.

POPCZYK, Maria (2008). Estetyczne przestrzenie ekspozycji muzealnych [The aesthetic spaces of museum expositions]. Kraków: Wydawnictwo Universitas. [In Polish]. ISBN: 97883242-0888-3.

PURCHLA, Jacek (2011). Dziedzictwo kulturowe a kapitał społeczny [Cultural heritage and social capital]. In: Matopolskie Studia Regionalne, 1, p. 5-8. [In Polish]. ISSN 2080-8151

REKDAL, Per (2013). About the Beauty of War and the Attractivity of Violence. In: MUCHITSCH, Wolfgang (ed.) Does War Belong in Museums? The Representation of Violence in Exhibitions. Bielefeld: Verlag, p. 123-130. PDF-ISBN 978-3-8394-2306-6.

REYNOLDS, Chris, BLAIR, William (2018). Museums and 'Difficult Pasts': Northern Ireland's 1968. In: Museum International, 70:3-4. Special Issue: Museums \& Contested Histories, p. 12-25. Online ISSN:1468-0033.

RICHARDS, Greg (2016). Cultural Tourism. In: MCMANUS, Paulette. (ed.) Archaeological Displays and the Public. Museology and Interpretation (2nd edition). London: Routledge, p. 1-12. ISBN-13: 978-1873132678.

RICHARDS, Greg. (ed.) (1996). Cultural Tourism in Europe. Wallingford: CABI. ISBN: 9780851991047.

RODELL, Dennis (March 2011). Urban Conservation in the 1960s and 1970s: A European Overview. In: Architectural Heritage, 21:1, p. 1-18; Online ISSN: 1755-1641.

ROSS, Max (July 2004). Interpreting the new museology. In: Museum \& Society, 2:2, p. 84-103. ISSN 1479-8360.

SARYUSZ-WOLSKA, Magdalena (2010). Turystyka uwikłana w pamięć zbiorową [Tourism involved in collective memory]. In: Kultura Wspótczesna, 3, p. 63-74. [In Polish]. ISSN 23001704.

SCOTT, James (2015). Objects and the Representation of War in Military Museums. In: Museum \& Society, 13:4, p. 489-502; ISSN 1479-8360.

SIMON, Nina (2010). The participatory museum. Santa Cruz: Museum. ISBN: 978-0615346502.

STYLIANOU-LAMBERT, Theopisti, BOUNIA, Alexandra (November 2012). War Museums and Photography. In: Museum \& Society, 10:3, p. 83-196. ISSN 1479-8360. 
TAMASHIRO, Roy, FURNARI, Ellen (2015). Museums for peace: agents and instruments of peace education. In: Journal of Peace Education, 12: 3, p. 223-235.

http://dx.doi.org/10.1080/17400201.2015.1092712. ISSN: 1740-0201.

TILDEN, Freeman (1957). Interpreting Our Heritage. Chapel Hill: The University of North Carolina Press. ISBN: 978-0807858677.

TUNBRIDGE, John, ASHWORTH, Gregory (1996). Dissonant Heritage: The Management of the Past as a Resource in Conflict. Chichester: Wiley. ISBN, 047194887X.

TYTHACOTT, Louise (November 2015). Trophies of War: Representing 'Summer Palace' Loot in Military Museums in the UK. In: Museum \& Society, 13:4, p. 469-488. ISSN 14798360.

Uczestnictwo ludności w kulturze w 2014 roku. Warszawa: Główny Urząd Statystyczny, 2016. https://stat.gov.pl/obszary-tematyczne/kultura-turystyka-sport/kultura/uczestnictwo-ludnosci-w-kulturze-w-2014-r-,6,2.html (accessed 23 September 2019). [In Polish].

URRY, John (2007). Spojrzenie turysty [Tourist gaze]. Warszawa: PWN. [In Polish]. ISBN: 97883-0115-051-8.

Ustawa z. dnia 21 listopada 1996 r. o muzeach. [The Act of 21 November 1996 on museums]. Dz. U. z 2012 r. poz. 987, z późn. zm. [In Polish].

UZZELL, David (1989). The Hot Interpretation of War and Conflict. In: UZZELL, David (ed.) Heritage Interpretation. Volume 1. The Natural and Built Environment. London, New York: Belhaven Press, p. 33-47. ISBN: 9780471947820.

VERBYTSKA, Polina, KUZMYN, Roman (2019). Between amnesia and the "war of memories": politics of memory in the museum narratives of Ukraine. In: Mureologia a kulturne dedicstvo, 7:2, p. 23-34. ISSN 2453-9759 (Online).

WAKER, Rob (2001). Postmodernism and nationalism. In: MOTYL, Alex. (ed.) Encyclopaedia of nationalism. San Diego: Academic Press, p. 611-630. ISBN: 9780080545240.

WELSCH, Wolfgang (2005). Estetyka poza estetyką. O nową postać estetyki. [Aesthetics beyond aesthetics. On a new shape of aesthetics]. Kraków: Wydawnictwo Universitas. [In Polish]. ISBN: 83-242-0434-2.

WHITMARSH, Andrew (November 2001). We will remember them. Memory and commemoration in war museums. In: Journal of Conservation and Museum Studies, 7, p. 1-15. E-ISSN: 1364-0429.

WINTER, Caroline (2018). The multiple roles of battlefield war museums: A study at Fromelles and Passchendaele. In: Journal of Heritage Tourism, 13:3, p. 211-223, DOI: 10.1080/1743873X.2017.1287189. ISSN:1743-873X.

WINTER, Jay (1995). Sites of Memory, Sites of Mourning: The Great War in European Cultural History. Cambridge: Cambridge University Press. ISBN: 9780521639880.

WITCOMB, Andrea (2003). Re-Imagining the Museum. Beyond the Mausoleum. London, New York: Routledge. ISBN: 978-0415220996.

WOŹNIAK, Michał (2018). Muzeum - pamięć - miejsce pamięci. [Museum - memory - site of memory]. In: DE ROSSET et al. (eds.) Muzeum a pamieć-forma, produkcja, miejsce. Materialy konferencii zorganizowanej w dniach 8-9 czerwca 2017 roku prezez Zakład Muzealnictwa Wydziatu Sztuk Pieknych Uniwersytetu Mikolaja Kopernika w Toruniu. Warszawa: Narodowy Instytut Muzealnictwa i Ochrony Zbiorów, p. 22-30. [In Polish]. ISBN 978-83-64889-31-8. 
YOUNG, Linda (1990). Globalisation, culture and museums: A review of theory. In: International Journal of Heritage Studies, 5:1, p. 6-15. doi.org/10.1080/13527259908722242. ISSN: 1470-3610.

ZHANG, Carol X., XIAO, Honggen, MORGAN, Nigel, LY, Tuan Phong (2018). Politics of memories: Identity construction in museums. In: Annals of Tourism Research, 73, p. 116-130. ISSN: 0160-7383.

\section{Internet sources}

http://prywatnemuzea.pl/muzea-zrzeszone (accessed 31 May 2019).

http:/ /www.muzeumwp.pl/ (accessed 17 September 2019).

www.1944.pl; museum1939.pl (accessed 03 October 2019).

www.stat.gov.pl (accessed 21 June 2019 and 05 August 2020).

https://www.muzea.net/ portal (accessed 21 June 2019).

https://www.museo.pl portal (accessed 21 June 2019).

Wikipedia (accessed 21 June 2019).

http://bip.mkidn.gov.pl/pages/rejestry-ewidencje-archiwa-wykazy/rejestry-muzeow.php (accessed 22 June 2019).

http://bip.mkidn.gov.pl/pages/rejestry-ewidencje-archiwa-wykazy/rejestry-muzeow.php (accessed 23 September 2019).

\section{Appendix}

The paper version of the online survey conducted among military museums in Poland (https://www.survio.com/survey/d/E8K3O7D3P9J2Y5H0W). The questionnaire was originally in Polish. In the published article, only the answers to selected questions (marked in bold below) have been analysed.

\section{Dear Member of the Museum Stuff}

\section{Military museums in Poland}

We cordially invite you to take part in a study of military museums in Poland. The research is conducted by the Department of Political and Historical Geography and Regional Studies at the University of Lódź and the Institute of Geography and Regional Development at the University of Wrockaw. Our aims are to create a comprehensive database for all institutions of this type in Poland, to compile the collected information, and to publish the results in a renowned scientific journal. We kindly ask you to fill in the questionnaire, which should not take more than several minutes. Thank you for your help and your time! Unless stated otherwise, it is possible to indicate one answer.

1. Full name of the museum (please fill in)

2. Foundation year of the museum (please fill in)

3. Founder (e.g. private person, community, government, denominational union, etc.) (please fill in)

4. Branch, if your institution belongs to a larger organization (please fill in)

5. Character of the structures, interiors, rooms within the museum operates (e.g. in a castle, a citadel, new building, open air museum, etc.) (please fill in) 
6. Thematic profile of the museum (what kind of artefacts are collected and facilitated) (please fill in)

7. Website (if exists) (please fill in)

8. Prices of entrance tickets (please fill in)

9. Percentage of the whole collection that is facilitated for visitors (please fill in)

10. How many items does the whole collection consist of (exhibited and collected in a museum store) (please fill in)

11. How many exhibition rooms are within the museum (please fill in)

12. Area of the museum (in sq. $\mathrm{m}$ ) (please fill in)

13. How many temporary exhibitions are organized on average per year? (please fill in)

14. How many permanent exhibitions are housed within the museum? (please fill in)

15. Please list the most valuable collection or their groups (up to five) in the museum giving a brief explanation (one or two sentences) (please fill in)

16. Who is the author of the idea and design of the exhibition? (choose one option)

Museum staff

Hired company

Other option(s), please explain

17. What is the general character of the whole exhibition in the museum? (choose one or more options)

Chronological

Thematic

Narrative

Historical (linked with specific historical époques)

Problem-oriented

Other option(s), please explain

18. In terms of selected exhibitions, the most frequently used kind of exhibition structure is (choose one or more options):

Chronological

Thematic

Narrative

Historical (linked with specific historical époques)

Problem-oriented

Other option(s), please explain

19. Place of historical authentic artefacts in the museum exhibition (choose one option):

Authentic historical artefacts constitute the entire museum exhibition

Authentic historical artefacts dominate in the museum exhibition, but it is also complemented by replicas of historical objects or/and other exhibition tools (traditional information boards, multimedia, etc.)

Authentic historical artefacts appear sporadically in the exhibition; the exhibition is mainly based on replicas of historical objects or/and other exhibition tools (traditional information boards, multimedia, etc.)

The exhibition is entirely based on replicas of historical objects or/and other exhibition tools (traditional information boards, multimedia, etc.)

20. Please describe the character of the main tools in the museum exhibition (choose one option): 
D. Chylińska, Ł. Musiaka: Military museums in Poland - between the past and the future

Entirely traditional, i.e. artefacts exhibited in display cases

Traditional enriched by some conventional thematic information boards

Traditional enriched by some conventional thematic information boards and some multimedia

Traditional enriched by some multimedia

Entirely based on multimedia

21. If multimedia displays are among the tools of the exhibition, please indicate which type? (choose one or more options)

2D films

3D films

360-degree videos

Educational games

Sound effects

Smell effects

Visual effects

Interactive 2D multimedia presentations

Interactive 3D multimedia presentations

Multimedia applications

Other option(s), please explain

22. Please describe how do visitors use the exhibitions (choose one option):

Independently

Independently but supported by a virtual tour guide

Only with a tour guide

Having an alternative: visiting independently or with a tour guide

23. In the museum, can one find: (indicate using an $X$ ):

\begin{tabular}{|l|l|l|l|}
\hline \multicolumn{1}{|c|}{ Yes } & No & $\begin{array}{c}\text { Partly (24. please } \\
\text { explain what does it } \\
\text { mean in this case) }\end{array}$ \\
\hline $\begin{array}{l}\text { Places for relaxation or } \\
\text { contemplation }\end{array}$ & & & \\
\hline $\begin{array}{l}\text { Elimination of physical } \\
\text { obstacles of access for } \\
\text { people with disabilities } \\
\text { (stairs, doorsteps, etc.) }\end{array}$ & & & \\
\hline $\begin{array}{l}\text { Adjustment of the } \\
\text { exhibition to make it } \\
\text { accessible for people with } \\
\text { disabilities (captions in } \\
\text { Braille, lowered showcases, } \\
\text { etc.) }\end{array}$ & & & \\
\hline $\begin{array}{l}\text { Adjustment of the } \\
\text { exhibition for foreign } \\
\text { visitors (e.g. information } \\
\text { in foreign languages, tour } \\
\text { guiding } \\
\text { in a foreign language) }\end{array}$ & & & \\
\hline
\end{tabular}

25. In which foreign languages has the museum exhibition been prepared? (please fill in) 
26. Who was the main target audience for the museum exhibition in terms of the choice of exhibits (choose one option)

Children

Youths and adults

People of various ages (including children)

Other options, please explain

27. Please describe the type of museum (choose one or more options)

Museum of battles, military campaigns, uprisings, and specific conflicts

Museums of military equipment

Biographical museums

War (itself) museums

Museums of military buildings and structures

Museums of selected military troops

Other option(s), please explain

28. Does the museum conduct scientific activities? (choose one option)

Yes

No

Other, please explain

29. If does, please explain with one or two sentences (please fill in)

30. If does, how many people are involved in these activities? (choose one option)

$1-2$

$3-4$

5 and more

31. Does the museum offer commercial services listed below? ( $p$ ut $X$ )

\begin{tabular}{|c|c|c|}
\hline & Yes & No \\
\hline Selling souvenirs & & \\
\hline $\begin{array}{c}\text { Selling scientific and } \\
\text { popular-science literature }\end{array}$ & & \\
\hline Catering service & & \\
\hline Other & 32. If does, please explain & \\
& & \\
\hline
\end{tabular}

33. Which kinds of promotional tools from listed below does the museum use? (choose one or more options)

Website with basic information (type of exhibition, opening hours, contact details, access)

Website with a virtual museum

Leaflets and posters

Advertisement in media, non-professional press

Promotional movies on regional TV

Promotional movies on state TV

Promotional movies on Internet (e.g. YouTube)

Advertisement on public transport 
D. Chylińska, Ł. Musiaka: Military museums in Poland - between the past and the future

\section{Fun page}

Promotion via social media (Facebook, Twitter, Instagram, Snapchat, other)

Sponsorship of cultural of entertainment events

Other, please explain

34. Does the museum cooperate with other museums? (choose one option)

Yes

No

Other, please explain

35. If does, please list them. (please fill in)

36. If does, please describe the character of this cooperation, choosing one from below listed (choose one option):

Cooperation of a scientific nature related to statutory activities of the museum (collecting, protecting and preserving exhibits)

Popularizing activity in terms of education, also with schools and units of territorial administration

Popularizing activity in terms of tourism, also with local, regional and national tourism organizations

Popularizing activity in partnership with NGOs

Other, please explain

37. Please describe the economic foundation of the museum operation by the percentage of share each of given source (please fill in)

\begin{tabular}{|l|l|}
\hline & Share $[\%]$ \\
\hline Own economic activity & \\
\hline State grants and donations, subsidies & \\
\hline Other, 38. please explain & \\
\hline
\end{tabular}

39. Please estimate a percentage share of selected groups of visitors in the total volume of tourist visits in the museum (please fill in)

\begin{tabular}{|l|c|}
\hline & Share $[\%]$ \\
\hline Domestic visitors & \\
\hline Foreign visitors & \\
\hline
\end{tabular}

40. Please estimate a percentage share of selected groups of visitors in the total volume of tourist visits in the museum (please fill in)

\begin{tabular}{|l|c|}
\hline & Share $[\%]$ \\
\hline Individual visitors & \\
\hline Groups & \\
\hline
\end{tabular}

41. How many staff are employed by the museum? Please count according to their position (please fill in)

\begin{tabular}{|l|l|}
\hline & Number \\
\hline Permanent workers & \\
\hline Temporary workers & \\
\hline
\end{tabular}


42. How many grants has the museum received based on financial support of (please fill in)

\begin{tabular}{|l|l|l|}
\hline & Number & $\begin{array}{l}\text { Total amount of } \\
\text { financing }\end{array}$ \\
\hline European Union & & \\
\hline The state & & \\
\hline $\begin{array}{l}\text { Other, } \\
\text { 43. please describe them }\end{array}$ & & \\
\hline
\end{tabular}

44. Please indicate the numbers of visitors for selected years (please fill in or send us data via an e-mail)

45. When was the museum last renovated in recent years? (please fill in) Describe the scope of the rennovations (please fill in)

46. Is the museum planning any investments? If so, please indicate what type of activity (choose one option)

Extension of the building

Increasing number of exhibition rooms

Increasing the volume of exhibits

Increasing outdoor space for collections

Other, please explain

47. Please describe seasonality of tourist flow in selected years per mouths (please fill in send us data via an e-mail)

48. Please describe the character of the exhibition (choose one option)

Exhibition exposes values collected exhibits themselves (uniqueness, rarity, aesthetic values, etc.)

Exhibition illustrates wider historical, cultural, social or political contexts

Other, please explain

49. Please describe the dominant style of museum narration used in the museum (choose one option):

Impersonal, factual, focused on material characteristics of objects

Personalized, combining items with their individual producers or selected groups of people, describing events through a biography of selected individuals or their groups

Mixed, 50. In what condition is this approach used?

Other, please explain 